NATIONAL LABORATORY

\title{
Bootstrapping a Sustainable North American PEM Fuel Cell Industry: Could a Federal Acquisition Program Make a Difference?
}

\section{October 2008}

\section{Prepared by}

Dr. David L. Greene

Oak Ridge National Laboratory

Dr. K. G. Duleep

Energy and Environmental Analysis, Inc., an ICF Company

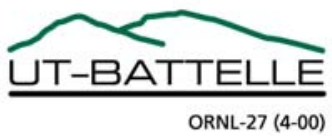




\section{DOCUMENT AVAILABILITY}

Reports produced after January 1, 1996, are generally available free via the U.S. Department of Energy (DOE) Information Bridge.

Web site http://www.osti.gov/bridge

Reports produced before January 1, 1996, may be purchased by members of the public from the following source.

National Technical Information Service

5285 Port Royal Road

Springfield, VA 22161

Telephone 703-605-6000 (1-800-553-6847)

TDD 703-487-4639

Fax 703-605-6900

E-mail info@ntis.gov

Web site http://www.ntis.gov/support/ordernowabout.htm

Reports are available to DOE employees, DOE contractors, Energy Technology Data Exchange (ETDE) representatives, and International Nuclear Information System (INIS) representatives from the following source.

Office of Scientific and Technical Information

P.O. Box 62

Oak Ridge, TN 37831

Telephone 865-576-8401

Fax 865-576-5728

E-mail reports@osti.gov

Web site http://www.osti.gov/contact.html

This report was prepared as an account of work sponsored by an agency of the United States Government. Neither the United States Government nor any agency thereof, nor any of their employees, makes any warranty, express or implied, or assumes any legal liability or responsibility for the accuracy, completeness, or usefulness of any information, apparatus, product, or process disclosed, or represents that its use would not infringe privately owned rights. Reference herein to any specific commercial product, process, or service by trade name, trademark, manufacturer, or otherwise, does not necessarily constitute or imply its endorsement, recommendation, or favoring by the United States Government or any agency thereof. The views and opinions of authors expressed herein do not necessarily state or reflect those of the United States Government or any agency thereof. 


\title{
BOOTSTRAPPING A SUSTAINABLE NORTH AMERICAN PEM FUEL CELL INDUSTRY: COULD A FEDERAL ACQUISITION PROGRAM MAKE A DIFFERENCE?
}

\author{
Dr. David L. Greene \\ Oak Ridge National Laboratory \\ Dr. K.G. Duleep \\ Energy and Environmental Analysis, Inc., an ICF Company \\ Report to the \\ Hydrogen Fuel Cells and Infrastructure Technologies Program \\ Office of Energy Efficiency and Renewable Energy \\ U.S. Department of Energy \\ Washington, D.C.
}

October 2008

Prepared by

OAK RIDGE NATIONAL LABORATORY

Oak Ridge, Tennessee 37831-6283

managed by

UT-BATTELLE, LLC

for the

U.S. DEPARTMENT OF ENERGY

under contract DE-AC05-00OR22725 



\section{TABLE OF CONTENTS}

Page

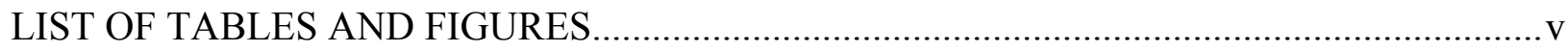

ACKNOWLEDGEMENTS .............................................................................................

1. OVERVIEW AND STUDY OBJECTIVES ...........................................................

2. ASSESSMENT OF INDUSTRY STATUS AND POTENTIAL NEAR-TERM

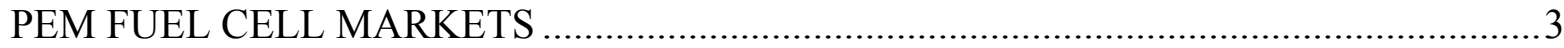

2.1 INDUSTRY STATUS AND MARKET OUTLOOK .................................................. 3

2.2 VIEWS ON DESIRABILITY AND TIMING OF GOVERNMENT ACQUISITION

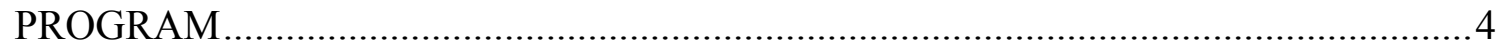

2.3 CURRENT PRICES AND COMPETITIVE PRICE POINTS ..................................5

2.4 LEAD TIMES TO EXPAND PRODUCTION .........................................................

2.5 FUEL CELL OEM SUPPLY CHAIN ....................................................................... 7

2.6 POTENTIAL FOR LEARNING-BY-DOING AND ECONOMIES OF SCALE ............7

2.7 IMPORTANCE OF HYDROGEN DELIVERY INFRASTRUCTURE ......................... 8

2.8 SIZE OF THE POTENTIAL PRIVATE SECTOR FUEL CELL MARKET ...................9

2.9 SIZE OF THE POTENTIAL FEDERAL FUEL CELL MARKET .............................. 9

3. ESTIMATING THE IMPACTS OF A GOVERNMENT ACQUISITION PROGRAM ......13

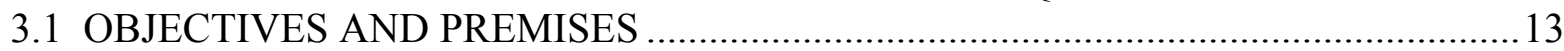

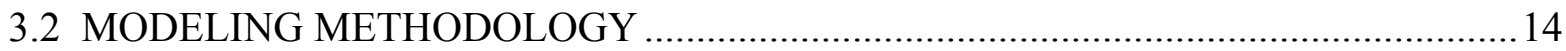

3.3 KEY ASSUMPTIONS AND SCENARIO DEFINITIONS ....................................... 16

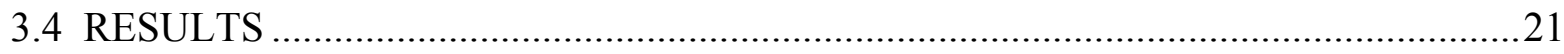

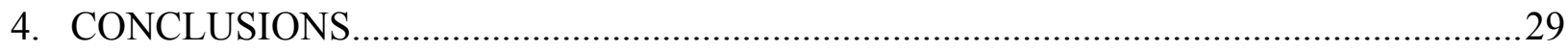

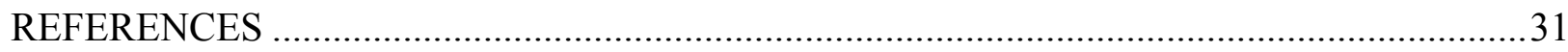





\section{LIST OF TABLES AND FIGURES}

$1 \quad$ Cost and Volume Targets for Non-automotive PEM Fuel Cell Markets.....................6

Federal Backup Power Fuel Cell Applications by Agency and Size.......................... 10

Assumptions about the Size of the Federal MHE Market ......................................... 11

Learning Curve Assumptions and Parameters ....................................................... 17

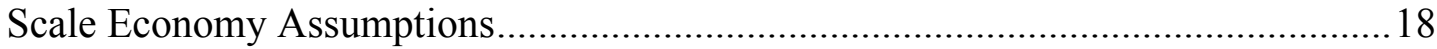

Initial Year Cost Assumptions for Fully Installed Fuel Cell Systems ......................19

Logit Choice Model Assumptions and Parameters.................................................. 19

1 Estimated worldwide hydrogen PEM fuel cell production for non-automotive

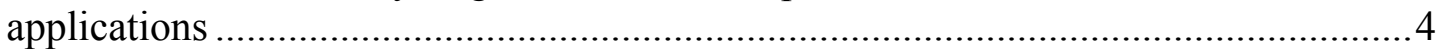

2 Asymptotic and power function experience curves for stack manufacturers ............17

$3 \quad$ Asymptotic and power function experience curves for OEMs ............................... 18

4 Choice functions determining fuel cell market shares as a function of price .............20

5 Assumed federal acquisitions of non-automotive fuel cells in Scenario 1 ...............20

6 Estimated effect of federal acquisitions program on PEM fuel cell system costs:

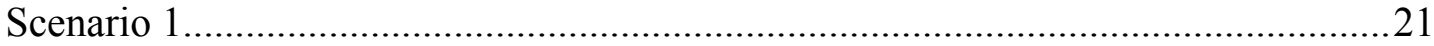

7 Estimated impact of federal acquisitions program on PEM fuel cell stack costs:

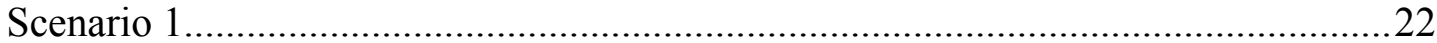

8 Estimated effect of federal acquisitions on PEM fuel cell system sales:

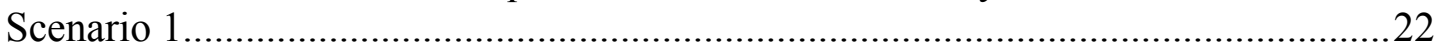

9 Estimated effect of federal acquisitions program on PEM fuel cell manufacturers'

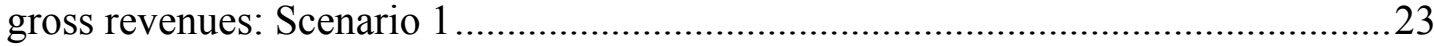

10 Estimated gross cost of federal PEM fuel cell system purchases: Scenario 1 ...........24

11 Estimated effect of federal acquisitions program on sales of PEM fuel cell systems: Scenario 2, doubled private sector price sensitivity .................................25

12 Assumed federal acquisitions of PEM fuel cell systems: Scenario 3 .....................26

13 Estimated effect of federal acquisitions on sales of PEM fuel cells: Scenario 3 .......26

14 Estimated effect of federal acquisitions on fuel cell system manufacturers' gross

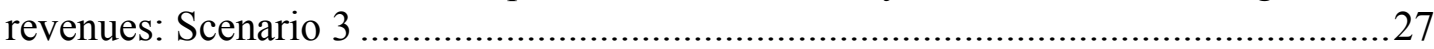

15 Estimated effect of federal acquisitions on PEM fuel cell system costs:

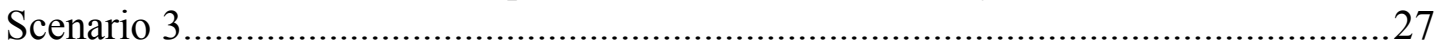

16 Estimated effect of federal acquisitions on PEM fuel cell stack costs:

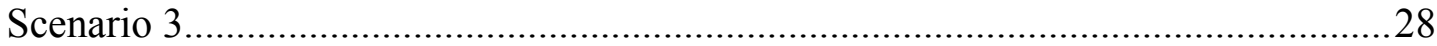

17 Estimated gross costs of federal acquisitions program: Scenario 3 .......................28 



\section{ACKNOWLEDGEMENTS}

The authors gratefully acknowledge the assistance of the following individuals:

Marcus Rothstein, Michael Perry, Prasad Kambli, James Whitton, Brian Scaria,

George Roberts and Robert Tierney, UTC Power

Tom Ollila and Warren Brown, Plug Power

Ethan Brown and Pat Hearn, Ballard

Katya Mahadevan, Battelle

Pete Devlin and Fred Joseck, DOE/HFCIT

Sujit Das and Zhenhong Lin, ORNL

Any errors or misinterpretations that may be present in this report are the sole responsibility of the authors. 



\section{OVERVIEW AND STUDY OBJECTIVES}

The North American Proton Exchange Membrane (PEM) fuel cell industry may be at a critical juncture. A large-scale market for automotive fuel cells appears to be several years away and in any case will require a long-term, coordinated commitment by government and industry to insure the co-evolution of hydrogen infrastructure and fuel cell vehicles (Greene et al., 2008). The market for non-automotive PEM fuel cells, on the other hand, may be much closer to commercial viability (Stone, 2006). Cost targets are less demanding and manufacturers appear to be close, perhaps within a factor of two, of meeting them. Hydrogen supply is a significant obstacle to market acceptance but may not be as great a barrier as it is for hydrogen-powered vehicles due to the smaller quantities of hydrogen required.

PEM fuel cells appear to be potentially competitive in two markets: (1) Backup power (BuP) supply, and (2) electrically-powered MHE (Mahadevan et al., 2007a, 2007b). There are several Original Equipment Manufacturers (OEMs) of PEM fuel cell systems for these applications but production levels have been quite low (on the order of 100-200 per year) and cumulative production experience is also limited (on the order of 1,000 units to date). As a consequence, costs remain above target levels and PEM fuel cell OEMs are not yet competitive in these markets. If cost targets can be reached and acceptable solutions to hydrogen supply found, a sustainable North American PEM fuel cell industry could be established. If not, the industry and its North American supply chain could disappear within a year or two.

The Hydrogen Fuel Cell and Infrastructure Technologies (HFCIT) program of the U.S. Department of Energy (DOE) requested a rapid assessment of the potential for a government acquisition program to bootstrap the market for non-automotive PEM fuel cells by driving down costs via economies of scale and learning-by-doing. The six week study included in-depth interviews of three manufacturers, visits to two production facilities, review of the literature on potential markets in North America and potential federal government procurements, development of a cost model reflecting economies of scale and learning-by-doing, and estimation of the impact of federal PEM fuel cell procurements on fuel cell system costs and the evolution of private market demand. This report presents the findings of that study. Section 2 outlines the status of the industry and describes potential markets based on interviews of manufacturers and the existing literature. Section 3 describes the modeling methodology including key premises and assumptions, and presents estimates of market evolution under four scenarios: (1) Base Case with no federal government procurement program, (2) Scenario 1, an aggressive program beginning with less than 200 units procured in 2008 ramping up to more than 2,000 units in 2012, (3) Scenario 2 which is identical to Scenario 1 except that the private market is assumed to be twice as sensitive to price, and (4) Scenario 3, a delayed, smaller federal procurement program beginning in 2011 increasing to a maximum of just over 1,000 units per year in 2012.

The analysis suggests that the aggressive program of Scenario 1 would likely stimulate a sustainable, competitive North American non-automotive PEM fuel cell industry. Given plausible assumptions about learning rates and scale economies, the procurements assumed in Scenario 1 appear to be sufficient to drive down costs to target levels. These findings are 
conditional on the evolution of acceptable hydrogen supply strategies, which were not explicitly analyzed in this study. Success is less certain under Scenarios 2 and 3, and there appears to be a strong probability that existing OEMs would not survive until 2011. In the Base Case, no program, a viable North American industry does not emerge before 2020. 


\section{ASSESSMENT OF INDUSTRY STATUS AND POTENTIAL NEAR-TERM PEM FUEL CELL MARKETS}

\subsection{INDUSTRY STATUS AND MARKET OUTLOOK}

The non-automotive, U.S. polymer electrolyte (PEM) fuel cell industry producing units of $1 \mathrm{~kW}$ or greater is focused primarily on two markets:

1. Backup electric power supply $(1-5 \mathrm{~kW})$. The size of this market and the potential for fuel cells to compete will be strongly affected by the recent FCC ruling that emergency communication systems must have 8 hours of continuous backup power. If that ruling stands, PEM fuel cell OEMs believe they will have a strong competitive position.

2. Material handling vehicles (e.g., forklifts, etc.) hybrid systems with 4-10 kW. These vehicles are typically hybrids, today using NiMH or lead-acid batteries or ultracapacitors but not using regenerative electrical energy.

The industry believes that where PEM fuel cells will compete with batteries in these applications, cost and performance targets are such that fuel cells have the potential to be economically competitive provided that production volumes can be increased and hydrogen availability issues can be resolved (Perry, 2007).

Most OEMs view themselves as designers, systems integrators and assemblers and do not consider manufacturing components such as stacks to be part of their core business. Ballard, however, is definitely in the stack manufacturing business and intends to stay there. The trend is for OEMs to buy finished components as commercial products from suppliers to the greatest extent possible. Ballard may supply stacks to system integrators, but will also rely on suppliers to provide stack parts.

Total cumulative production of backup fuel cell units is on the order of several hundred Figure 1). Estimates of the total production of backup units produced in 2007 range from 200 to 500 . Somewhat more than 200 fuel cell systems for MHE were also produced in 2007 by all manufacturers combined (U.S. Fuel Cell Council, 2006). Fuel cell systems for cogeneration applications are smaller, on the order of $1-2 \mathrm{~kW}$ and are produced almost entirely for the Japanese residential market. If as many as 1,500 total PEM fuel cell units are produced in 2008 that would be considered a large number and one unlikely to be reached without continued or expanded government assistance. A reasonable baseline assumption for the 1-10 kW PEM fuel cell industry, without a government acquisition program and without an 8-hour requirement for emergency backup power, would be 400 to 500 units per year. If the units (including cabinetry but not fully installed on site) sell for $\$ 20,000$ to $\$ 30,000$, this would put the total size of the industry at $\$ 8-\$ 15$ million. 


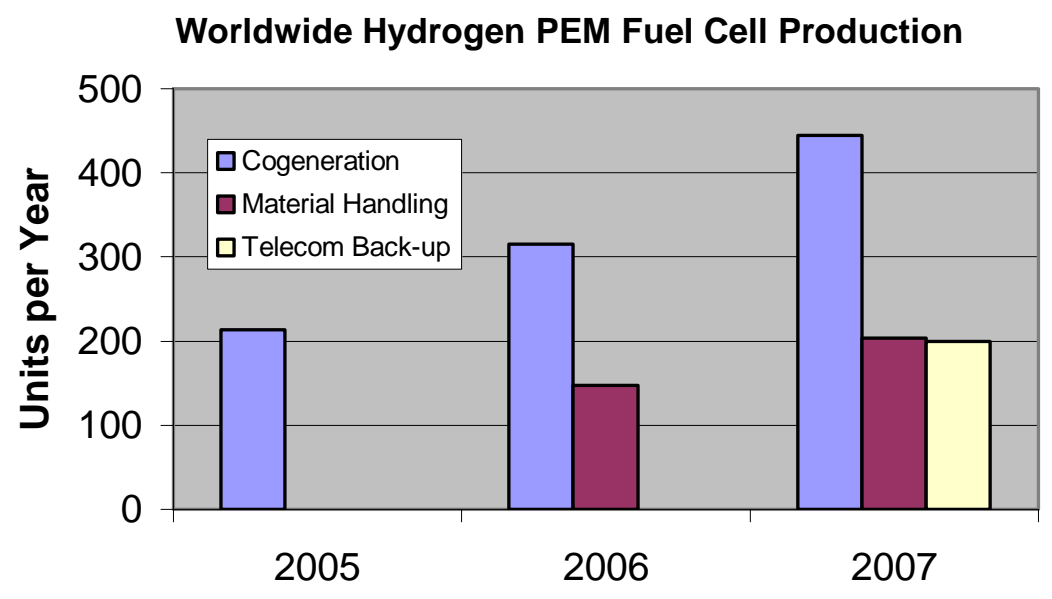

Figure 1. Estimated worldwide hydrogen PEM fuel cell production for non-automotive applications.

Both markets appear to be sufficiently large to sustain a viable domestic industry provided that fuel cell system costs can be brought down by about a factor of two and that an adequate hydrogen supply infrastructure can be developed. Analysis of the likely market sensitivity to cost suggests that fuel cell system costs will need to be in the vicinity of $\$ 2000$ to $\$ 3,000$ per $\mathrm{kW}$ (not installed) and hydrogen costs will need to be on the order of $\$ 7$ to $\$ 8$ per $\mathrm{kg}$ for fuel cell systems to compete (Stone, 2005).

Domestic fuel cell manufacturers appear to be poised to expand output to levels of thousands of units per year within 1 to 2 years, provided that these two major hurdles can be overcome. In some cases, the capital investment to produce 3,000 to 10,000 units per year has already been made and could be ramped up in less than a year. Where a commercial product has not yet been introduced, production levels of several hundred units per year could be achieved this year, ramping up to thousands of units per year would take 2-3 years.

\subsection{VIEWS ON DESIRABILITY AND TIMING OF GOVERNMENT ACQUISITION PROGRAM}

The OEMs believe that the non-automotive fuel cell industry in North America is at a tipping point. Prompt action would likely establish a viable industry within 3-5 years. Delay could be fatal. 2015 is too far in the future for OEMs to focus on; their time horizon ends in about 2012. They believe that if they can be successful over that period, they will have established a sustainable industry. The emerging industry faces three key barriers: (1) driving down the cost of their product, (2) creating a refueling infrastructure, and (3) proving the performance of their products to potential customers. OEMs view the first two as the most difficult and most critical. The OEMs believe that they have only a few years in which to overcome these barriers and establish a viable industry. They believe that a meaningful program of government acquisitions could play a crucial role in bootstrapping the non-automotive U.S. fuel cell industry. 
In the view of the OEMs, waiting until 2011 to begin such a program will be too late. What is needed, in their view, is a program that begins at a modest level this year or in fiscal year 2009 at the latest, and ramps up to a level that will have a meaningful impact no later than 2010 . For the past several years the fuel cell industry has been persuading its suppliers that the market will soon take off. Today, the OEMs are experiencing "supplier fatigue" because the market has not taken off. Unless they can show a viable market soon, they believe they will not be able to convince the supply chain to make the necessary investments in production capacity and they will lose most if not all of their North American supply base.

To date, government support has been highly beneficial to the fuel cell industry, providing critical funding for research, development and demonstration. The up to $\$ 1,000 / \mathrm{kW}$ tax credit for fuel cell purchasers has also been helpful but is not sufficient in most cases to overcome the twin barriers of early high costs due to low volume production and the lack of an appropriate hydrogen supply infrastructure. A government acquisition program targeted at the two principal products, backup power supply and materials handling vehicles, is a logical next step, they believe, and could have a game-changing impact.

U.S. fuel cell OEMs are in different positions. Some are just on the threshold of offering a commercial fuel cell powerplant. Others have been selling systems commercially at low levels (tens or hundreds) for 2 to 4 years with modest success despite the substantial barriers they face. None, however, have a stable and reliable foundation of demand that enables them to scale up to stable, economical volumes, establish reliable relationships with suppliers and consistently benefit from learning by doing. For all, even a modest level of guaranteed government acquisitions on the order of a few hundred units annually per manufacturer could make a crucial difference.

While the OEMs would most definitely welcome a government fuel cell acquisition program, they also believe it must be well thought out so that fuel cells are effectively utilized by the purchasers. It must also be large enough to stimulate the production volumes that will be needed to get fuel cell system costs from $\$ 6,000$ per $\mathrm{kW}$ (uninstalled) to the vicinity of $\$ 3,000$ per $\mathrm{kW}$. Such volumes are also necessary to ensure the needed impact on hydrogen supply. Also, incentives such as the up to $\$ 1,000$ tax credit for fuel cell system purchases are beneficial in helping to stimulate demand and should be continued, in the OEM's view.

We find the OEMs assertions to be credible. The entire U.S. industry produced a few hundred units last year. We toured a single plant with the capacity to produce up to 10,000 units per year that was almost idle on the day we visited. There does indeed appear to be an opportunity for a reasonable government acquisition program to have a major impact on product costs and on the overall viability of the U.S. fuel cell industry viability.

\subsection{CURRENT PRICES AND COMPETITIVE PRICE POINTS}

The cost of fuel cell systems needs to come down by roughly a factor of two or more to establish a stable, competitive industry. Our own analysis of recent transaction prices for fully-installed fuel cell systems in backup power applications indicates a range of $\$ 8,000$ to $\$ 12,000$ per $\mathrm{kW}$. 
The fuel cell alone accounts for about $40 \%$ of the installed cost in these estimates. This would make a typical $5 \mathrm{~kW}$ system quite expensive in comparison to the established alternatives (battery or diesel genset). The reaction of OEMs to our price estimate for current units was mixed, most thinking it was a little too high, others thinking it was about right for a first time full installation cost. At even low but stable volume, a useful cost range might be $\$ 6,000$ to $\$ 8,000$ per $\mathrm{kW}$ for a moderate production scale ( 250 units/year) fully installed backup power or materials handling unit purchased today. Some believe that the cost per $\mathrm{kW}$ of a fuel cell system, including balance of plant and storage should eventually be in the $\$ 2,000$ to $\$ 3,000$ price range to be fully competitive with current systems. (Current lead-acid battery systems for forklifts cost $\$ 3,000$ to $\$ 4,000$ today.) Each of the major components (stack, balance of plant and hydrogen storage) is now about $1 / 3$ of the total capital cost. Today, the cost for the stack alone is about $\$ 2,000$ per $\mathrm{kW}$.

The following cost targets for fuel cell stacks only (not balance of plant and storage and not fully installed) appear to be consistent with the industry's view of what it will take to be fully competitive in the three major markets for non-automotive PEM fuel cells (Table 1). Again, the residential cogeneration market appears to be limited to Japan at present.

Table 1. Cost and Volume Targets for Non-automotive PEM Fuel Cell Markets

\begin{tabular}{lcc}
\hline Application & Volume (units/yr./mfgr.) & Cost per kW (stack only) \\
\hline Material handling & $5,000-8,000$ & $\$ 400-\$ 500$ \\
Telecom backup power & $6,000-12,000$ & $\$ 1,000-\$ 1.500$ \\
Residential cogeneration & $4,000-8,000$ & $\$ 2,000-\$ 3,000$ \\
\hline
\end{tabular}

There seems to be agreement that a reasonable long-run, high-volume competitive price point for the industry is in the vicinity of $\$ 3,000$ per $\mathrm{kW}$, installed. OEMs believe there will be a meaningful commercial market at $\$ 4,000 / \mathrm{kW}$ to as much as $\$ 6,000 / \mathrm{kW}$ for those applications that value the advantages of fuel cell power. At this point, OEMs believe that they could effectively compete with battery and internal combustion engine generated backup power and claim a significant share of the market. Volumes per manufacturer would need to be on the order of two thousand units per year. A market of 5,000 units per year by 2011 could be enough to establish a viable North American industry, in the OEMs view.

\subsection{LEAD TIMES TO EXPAND PRODUCTION}

OEMs are in different positions with respect to the ability to increase production. Some are clearly capable of producing thousands of units per year with less than a year's notice because they already have the capital investment in place. These manufacturers see no problems in producing at least 1,000 units within a year and 5,000 units within 2-3 years. Those who have not yet launched commercial products might need 6 months or so to produce as many as 50 units, a year to ramp up to 100-200 units per year and 2 years to expand to volumes in the range of $\sim 500$ units per year. 


\subsection{FUEL CELL OEM SUPPLY CHAIN}

The OEMs interviewed assert that there is still a meaningful North American supply chain for fuel cell components, including stacks, compressors, power controls, condensers and batteries. It appears that they see themselves as systems integrators and do not expect to produce stack components or even the membrane electrode assembly (MEA) themselves. If a market is established, we anticipate that they will source the entire fuel cell stack as a unit from a handful of stack suppliers. At present, they are buying many of their components from domestic suppliers. However, these sub-system suppliers may be reliant on Japanese suppliers for some specialty materials and the catalyst. Due to the lack of any significant market to date, they contend that unless the U.S. market is established soon, the domestic supply chain is likely to disappear. In their view, Japan has established the most solid PEM supplier base in the world. The U.S. base, on the other hand, is at risk.

Japan has succeeded in creating a small but stable market for power units less than $10 \mathrm{~kW}$ with their residential fuel cell and backup power programs through large scale government support. Available statistics indicate that $80 \%$ of worldwide fuel cell units installed in the 1 to $10 \mathrm{~kW}$ range are in Japan. As a result, many large manufacturers like Toho-Tenax, Asahi Chemicals and Tanaka Kikinzoku have continued to maintain fuel cell related R\&D and offer a commercial product for fuel cell stack components. In contrast, the lack of a stable market in North America and the earlier unrealistic growth projections have made many suppliers wary and firms are rapidly dropping out of the fuel cell component market. If nothing happens to increase sales by 2012, there is an expectation that the supply base will become almost completely Asian.

\subsection{POTENTIAL FOR LEARNING-BY-DOING AND ECONOMIES OF SCALE}

There appear to be very substantial opportunities for process improvements to lower costs both in assembly and in the supply chain. The industry is very young (see Figure 1) and there appear to be large opportunities for cost reductions via both learning-by-doing and scale economies. We observed that much of the current assembly process is done by hand, although there is substantial variability across manufacturers, depending on the stage of product development. OEMs noted that many of their suppliers are also hand fabricating their products due to low volumes.

Very substantial improvements have already been made. A complete redesign of one OEM's assembly processes cut in half the labor hours required to produce a $5 \mathrm{~kW}$ fuel cell unit. Time required to test the units was reduced by an order of magnitude while improving quality. Another noted several reductions in labor costs on the order of $10 \%$ each from moving elements of the assembly from hand to automated processing. Still, current assembly processes are laborintensive.

For fuel cell system assembly, achieving scale economies (3,000 to 10,000 units per plant per year) would go a long way towards meeting the competitive price point $(\$ 2,000$ to $\$ 3,000$ per $\mathrm{kW}$ ) but would not be sufficient, according to industry sources we interviewed. Component prices must also come down. 
However, because fuel cell system OEMs see their role as designers and assemblers rather than component manufacturers, much or most of the learning-by-doing and scale economies will be realized in the manufacturing of components (DC/DC transformers, fuel cell stacks including plate manufacturing and sealing, batteries, high-pressure regulators, etc.). Large opportunities for learning and scale economies are believed to exist in stack design and manufacture, for example. Lesser opportunities may exist in balance of plant, depending on the system design. For air-cooled fuel cell systems, the balance of plant is already a greatly simplified and compact system. For water-cooled systems this is not the case.

The OEMs saw opportunities for learning-by-doing at all levels: component suppliers, OEMs and global industry-wide. Where OEMs are largely system designers and assemblers, learning may occur predominantly (up to $80 \%$ ) outside of the OEM in the supply chain and global market. Learning is also important on the customer side. Through experience OEMs learn how customers use fuel cells and which features are most valued. They can then translate that knowledge into improved fuel cell system designs. Although it appears that the hydrogen supply components (storage tanks, regulators, etc.) are a well established market and might therefore afford little opportunity for learning and scale economies, the OEMs generally disagree. They point out that PEM fuel cells are a new application for hydrogen supply systems, and are convinced that there are many opportunities to improve designs and reduce component costs.

\subsection{IMPORTANCE OF HYDROGEN DELIVERY INFRASTRUCTURE}

The OEMs view the lack of a hydrogen delivery infrastructure to be a significant barrier to market development. Hydrogen suppliers are accustomed to delivering tanks to customers on a regular basis. Backup power installations, on the other hand, require very infrequent fuel deliveries because hydrogen is used only during rare power failures. This means that storage tanks are not cycled frequently thereby increasing their cost per unit of hydrogen sold. Backup power sites (especially communication towers) are also often difficult for conventional hydrogen delivery trucks to access and fuel delivery may be needed when ambient conditions are poor, e.g., soon after a storm when the backup power has been operating for 8 or more hours and its fuel supply is running low.

Materials handling applications require far more hydrogen throughput, creating entirely different hydrogen delivery challenges. For motive power fuel cells, the lack of hydrogen delivery infrastructure is the biggest barrier to market success. Current practice is to deliver hydrogen in tube trailers which are left at the materials handling site until the hydrogen is used up and then they are replaced. In both cases, better solutions are needed.

A reasonable cost target for delivered hydrogen for non-automotive applications is $\$ 7$ to $\$ 8$ per $\mathrm{kg}$. Where hydrogen use is concentrated, for example a large materials handling center with 1520 forklifts, on-site hydrogen production via steam methane reforming may be able to meet or beat this cost target. For backup power applications, hydrogen suppliers will need to find innovative solutions if such a cost target is to be met. 
Determining the market sizes at which improved hydrogen infrastructure solutions would emerge is beyond the scope of this study but is clearly important to determining the point at which a viable, self-sustaining market for PEM fuel cells would become established. Some expressed the view that for backup power applications, perhaps 200-500 sites per metropolitan area would be needed to establish an acceptable hydrogen supply base. For motive power, on the order of 1,000 materials handling units would make a viable market for commercial hydrogen supply.

\subsection{SIZE OF THE POTENTIAL PRIVATE SECTOR FUEL CELL MARKET}

The potential private sector market for PEM fuel cells has been extensively studied by Mahadevan et al. (2007b, appendix C). They investigated 20 stationary applications, from airports and amusement parks to ski resorts and water and wastewater treatment facilities, and ten specialty vehicle applications from electric bicycles to wheelchairs. They concluded that Backup Power, especially telecom applications, and Materials Handling Equipment (MHE) were the most promising commercial applications.

Based on factory shipments, about half of the MHE units produced in the United States are class 1-3 battery powered units and half are larger internal combustion engine (ICE) powered units (Mahadevan et al., 2007b, table 3-16). The same source estimates that the total U.S. population of ICE forklift trucks was 750,000 in 2006. There is no comparable data for battery powered units in operation but if we assume a 50/50 split similar to factory shipments, then there would also be 750,000 battery powered units in operation. To be conservative, we assume that only 250,000 of these would be convertible to PEM fuel cell power.

- $1 \mathrm{~kW}$ BuP market size 125,000 units, 5\% replacement per year, 2\%/yr. growth.

- $5 \mathrm{~kW}$ BuP market size 125,000 units, 5\% replacement per year, 2\%/yr. growth.

- $5 \mathrm{~kW}$ MHE market size 250,000 units, annual replacement of 5\% per year, $2 \%$ growth.

\subsection{SIZE OF THE POTENTIAL FEDERAL FUEL CELL MARKET}

Mahadevan et al. (2007a) have estimated the potential for federal acquisitions of fuel cells for backup power and MHE. Tables 2-4 below have been taken directly from their presentation. Mahadevan et al. estimate the total size of the federal backup power market at nearly 20,000 units, of which $6.7 \%$ are replaced each year (Table 2). They further estimate that $75 \%$ of these units could be replaced by fuel cells.

Table 2. Federal Backup Power Assumptions

\begin{tabular}{ll}
\hline Total Market Size & 19,924 \\
Annual Replacement \% of Installed Base & $6.7 \%$ \\
FAA Market Growth Rate & $5 \%$ \\
Other Market Growth Rate & $0 \%$ \\
Fuel Cell Purchases as \% of Total Annual & $75 \%$ \\
Purchases & \\
\hline
\end{tabular}

Source: Mahadevan et al., 2007a. 
Most of the federal backup power applications, however, call for small units of $1 \mathrm{~kW}$, with less than $20 \%$ requiring larger $5 \mathrm{~kW}$ systems (Table 3). Power backup for FAA radio towers is by far the largest market segment.

Table 3. Federal Backup Power Fuel Cell Applications by Agency and Size

\begin{tabular}{|c|c|c|c|c|c|c|c|}
\hline $\begin{array}{l}\text { Market and } \\
\text { Application }\end{array}$ & $\begin{array}{l}\text { Market } \\
\text { Size, } \\
\text { units }\end{array}$ & $\begin{array}{c}\text { Size of } \\
\text { PEMFC } \\
(\mathrm{kW})\end{array}$ & $\begin{array}{c}\text { Total } \\
\text { Annual } \\
\text { Purchases } \\
\end{array}$ & $\begin{array}{l}\text { Total Annual } \\
\text { Purchases of } \\
\text { PEMFC } \\
\end{array}$ & $\begin{array}{c}\text { Cost Per } \\
\text { PEMFC }(\$)\end{array}$ & $\begin{array}{c}\text { Installation } \\
\text { Cost }(\$)\end{array}$ & $\begin{array}{c}\text { Cost } \\
(\text { million } \$) \\
\end{array}$ \\
\hline FAA - Radio Towers & 15,000 & 1 & 1,750 & 1,313 & 6,740 & 4,000 & 14.1 \\
\hline $\begin{array}{l}\text { DHS - Radio Repeater } \\
\text { Towers and Border } \\
\text { Entry Points }\end{array}$ & 200 & 5 & 200 & 150 & 15,940 & 18,000 & 5.1 \\
\hline $\begin{array}{l}\text { NOAA - Weather } \\
\text { Radio, Automated } \\
\text { Surface Observing } \\
\text { Systems }\end{array}$ & 1,824 & 5 & 122 & 91 & 15,940 & 18,000 & 3.1 \\
\hline $\begin{array}{l}\text { NOAA - Upper-air } \\
\text { Observations Program }\end{array}$ & 800 & 1 & 53 & 40 & 6,740 & 4,000 & 0.4 \\
\hline $\begin{array}{l}\text { USDA - Fire Incident } \\
\text { Camps, Radio Repeater } \\
\text { Sites }\end{array}$ & 1,000 & 5 & 66 & 50 & 15,940 & 18,000 & 1.6 \\
\hline $\begin{array}{l}\text { BoR - Communication } \\
\text { Sites }\end{array}$ & 100 & 5 & 7 & 5 & 15,940 & 18,000 & 0.2 \\
\hline $\begin{array}{l}\text { DOD - Radio } \\
\text { Transmitter Sites }\end{array}$ & 1,000 & 1 & 67 & 50 & 6,740 & 4,000 & 0.5 \\
\hline Total & 19,924 & & 2,265 & 1,699 & & & $\$ 27.1$ \\
\hline
\end{tabular}

Source: Mahadevan et al., (2007a).

The U.S. Postal Service (USPS) appears to be the largest market for MHE (forklifts), in part because it owns twice as many as the Defense Logistics Agency but also because it uses them more intensively and thus replaces them twice as often (Table 4). As a result, $80 \%$ of the estimated annual purchases of forklifts are by the USPS. Assuming much lower fuel cell market penetration rates of $5 \%$ to $20 \%$, Mahadevan et al. (2007a) estimate that total federal purchases could amount to 472 units per year. 
Table 4. Assumptions about the Size of the Federal MHE Market

\begin{tabular}{|c|c|c|c|c|c|c|}
\hline $\begin{array}{c}\text { Federal } \\
\text { Market } \\
\text { Segment }\end{array}$ & $\begin{array}{c}\text { Forklift } \\
\text { Type }\end{array}$ & $\begin{array}{l}\text { Market Size } \\
\text { (Units) }\end{array}$ & $\begin{array}{c}\text { Annual } \\
\text { Replacement } \\
\text { Purchases, \% of } \\
\text { Installed Base }\end{array}$ & $\begin{array}{c}\text { Annual } \\
\text { Replacement } \\
\text { Purchases (Units) }\end{array}$ & $\begin{array}{l}\text { Adoption } \\
\text { Rate }(\%)\end{array}$ & $\begin{array}{c}\text { Total Annual } \\
\text { Purchases } \\
\text { (Units) }\end{array}$ \\
\hline \multirow{4}{*}{$\begin{array}{l}\text { DOD, } \\
\text { Defense } \\
\text { Logistics } \\
\text { Agency }\end{array}$} & Class 1 & 2,000 & 10 & 200 & 20 & 40 \\
\hline & Class 2 & 1,000 & 10 & 100 & 5 & 5 \\
\hline & Class 3 & 1,000 & 10 & 100 & 20 & 20 \\
\hline & Class 1 & 5,088 & 20 & 1,018 & 20 & 204 \\
\hline USPS & Class 3 & 5,088 & 20 & 1,018 & 20 & 204 \\
\hline Total & & 14,175 & & 2,435 & & 472 \\
\hline
\end{tabular}

Source: Mahadevan et al., (2007a). 



\section{ESTIMATING THE IMPACTS OF A GOVERNMENT ACQUISITION PROGRAM}

\subsection{OBJECTIVES AND PREMISES}

The objective of a government acquisition program for non-automotive PEM fuel cells would be to aid manufacturers in reducing costs through learning-by-doing and increased scale of production so that within a short period of time they would be able to compete effectively in the marketplace. This would establish a small but sustainable North American PEM fuel cell industry with the expertise and manufacturing experience to evolve into a much large automotive PEM fuel cell industry.

Whether or not this objective is achievable depends on three key factors:

1. Is the private market for non-automotive PEM fuel cells large enough to sustain enough North American OEMs for a competitive market and a viable supplier base?

2. Is the government market for non-automotive fuels cells large enough to have a significant effect on PEM fuel cell costs?

3. Could government acquisitions drive down costs far enough over a short period of time (e.g., 5 years) to allow OEMs to compete effectively in private markets?

Fortunately the sizes of the private and governmental markets have been studied and quantified very recently by Battelle (Mahadevan et al., 2007a \& 2007b), and those studies are used heavily in this analysis.

To determine whether feasible levels of government purchases could bring down the prices of fuel cell systems to competitive levels, we have constructed a spreadsheet model incorporating the effects of learning-by-doing and scale economies. The model starts with our best estimates of the current costs of PEM fuel cell system, current production volumes and cumulative production to date. We then estimate the degree to which government purchases of fuel cell systems might bring down costs as a function of experience (measured by cumulative production) and scale (measured by volume per manufacturer). The key parameters of the scale and learning function must be assumed; in the absence of a historical record there is no known way to determine parameter values in advance (IEA, 2000).

Lower prices may eventually allow fuel cell systems to compete with batteries for backup-power and materials handling applications. We simulate this potential market response using economic choice models that depend on the price of the fuel cell systems. These models are calibrated by assumed price elasticities and target price levels at which fuel cell units are expected to compete on an equal footing with battery systems.

Important factors not included in the fuel cell model are the cost and availability of hydrogen and the potential for competing systems to improve over time in response to the challenge from fuel cells. These key factors were excluded so that the project could be completed on time, given the 
resources available. It would be desirable to investigate these issues in detail before ramping up to a full-scale government acquisition effort.

Clearly, the usefulness of the modeling analysis rests on the reasonability of its assumptions. We have tried to choose plausible but conservative values for key parameters, preferring to underestimate rather than overestimate the impact of a possible government acquisition program.

\subsection{MODELING METHODOLOGY}

The PEM fuel cell cost model predicts the cost in each year as a product of cost in the base year times a learning effect, times a scale effect. The three types of fuel cell systems $(1 \mathrm{~kW} \mathrm{BuP,} 5$ $\mathrm{kW}$ BuP, and $5 \mathrm{~kW}$ MHE) are modeled separately.

$$
\text { Current Cost }=(\text { Initial Cost }) \times(\text { Learning Effect }) \times(\text { Scale Effect })
$$

Fuel cell stack costs and the remainder of fuel cell system costs are modeled separately. The remaining system costs include the fuel cell system balance of plant plus equipment for hydrogen supply, such as tanks, valves and regulators.

$$
\begin{aligned}
& \text { System Cost }=\left(\begin{array}{ll}
\text { Stack } & \text { Cost }
\end{array}\right) \times\left(\begin{array}{lll}
\text { Stack } & \text { LBD }
\end{array}\right) \times\left(\begin{array}{lll}
\text { Stack } & \text { Scale }
\end{array}\right) \quad+ \\
& (\text { Remainder Cost }) \times(\text { Remainder LBD }) \times(\text { Remainder Scale })
\end{aligned}
$$

Government purchases of fuel cell systems are specified exogenously but private market purchases equal the total market size times an economic choice function that depends on the price of the fuel cell system. The market size is calculated by multiplying the total number of units in use times an annual replacement rate.

$$
\text { Market Size }=(\text { Number of existing units }) \times(\text { Fuel cell market share })
$$

Scale economies depend on the total annual volume of production $\mathrm{X}_{\mathrm{t}}$, the number of manufacturers, $\mathrm{N}$, a reference volume $\mathrm{x}_{\mathrm{o}}$ corresponding to the initial system cost estimate $\mathrm{C}\left(\mathrm{x}_{\mathrm{o}}\right.$, $\mathrm{Z}_{\mathrm{o}}$ ), and a "full scale" production volume $\mathrm{x}_{\max }$, at which full scale economies are assumed to be realized, and a constant elasticity of scale parameter, $\eta$. If $x_{t} \geq x_{\max }$, then the scale economies function is assumed to equal equation 1. This caps the maximum scale effect at $\left(\mathrm{x}_{\mathrm{t}} / \mathrm{x}_{\mathrm{o}}\right)^{\eta}$.

$$
\text { If } \frac{X_{t}}{N}=x_{t} \geq x_{\max } \text { then }\left(\frac{x_{\max }}{x_{o}}\right)^{\eta} \text { otherwise }\left(\frac{x_{t}}{x_{o}}\right)^{\eta}
$$

Learning-by-doing is assumed to be an asymptotic function of cumulative production at time $\mathrm{t}$, $\mathrm{Z}_{\mathrm{t}}$, a reference level of cumulative production, $\mathrm{Z}_{\mathrm{o}}$, and three coefficients, $\mathrm{A}_{\mathrm{o}}, \mathrm{A}_{1}$, and $\mathrm{b}$. The reference cumulative production serves as a scaling factor for $\mathrm{b}$. $\mathrm{A}_{\mathrm{o}}$ is the asymptotic reduction in cost due to learning-by-doing, since as $Z_{t}$ gets large the remainder of the expression in 
equation 2 goes to zero. As cumulative production goes to infinity, the rate of learning also approaches zero.

$$
A_{o}+A_{1} e^{b\left(\frac{Z_{t}}{Z_{o}}\right)}
$$

Learning-by-doing and scale economies are modeled separately for OEMs and fuel cell stack manufacturers, each having its own different learning curve parameters. For stack manufacturers experience is measured by the total number of $\mathrm{kWs}$ produced. For OEMs experience is measured by the total number of units produced, regardless of their power rating. Initial stack cost is subtracted from total installed system cost to yield an initial year estimate of the cost of assembly, balance of plant and hydrogen supply components. The cost of the fuel cell stack, computed by multiplying estimated $\$ / \mathrm{kW}$ times stack size, is then added to produce the estimated total system cost.

Cost is a function of the system cost in the initial year, $\mathrm{C}\left(\mathrm{X}_{\mathrm{o}}, \mathrm{Z}_{\mathrm{o}}\right)$, and the volume of production per manufacturer and cumulative production in year $t$, as shown in equation 3 . Variables and parameters for stack manufacturers are subscripted with an S, while OEMs are subscripted with a B for "balance" of system. Production per manufacturer is assumed to be the average production per manufacturer or total industry production $\mathrm{X}_{\mathrm{t}}$, divided by the number of manufacturers, $\mathrm{N}$. System power is $\mathrm{n}$, in $\mathrm{kW}$.

$C\left(X_{t}, Z_{t}\right)=C\left(X_{B o}, Z_{B o}\right)\left(\frac{X_{B t} / N_{B}}{X_{B o}}\right)^{\eta_{B}}\left(A_{B o}+A_{B 1} e^{\beta_{B}\left(\frac{Z_{B t}}{Z_{o B}}\right)}\right)+n C_{S}\left(X_{S o}, Z_{S o}\right)\left(\frac{X_{S t} / N_{S}}{X_{S o}}\right)^{\eta_{S}}\left(A_{S o}+A_{S 1} e^{\beta_{S}\left(\frac{Z_{S t}}{Z_{o S}}\right)}\right)$

Logit choice models are used to estimate the impact of reduced fuel cell costs on the level of market demand over time for the three types of systems: (1) Small (1 kW) BuP, (2) Large (5 kW) $\mathrm{BuP}$, and (3) $5 \mathrm{~kW}$ MHE. Given estimates of the total market size for each of the three types of equipment, $\mathrm{Q}_{1 \mathrm{BuP}}, \mathrm{Q}_{5 \mathrm{BuP}}$, and $\mathrm{Q}_{\mathrm{MHE}}$, the logit models are used to predict the share of each market that will be captured by PEM fuel cells as a function of their cost P.

$$
\begin{aligned}
& q_{\text {BuP }}=Q_{1 \text { BuP }} \frac{1}{1+e^{a_{1}+b_{1} P_{\text {BuP }}}}+Q_{5 \text { BuP }} \frac{1}{1+e^{a_{2}+b_{2} P_{5 B U P}}} \\
& q_{M H E}=Q_{M H E} \frac{1}{1+e^{a_{3}+b_{3} P_{M H E}}}
\end{aligned}
$$

The parameters $\mathrm{a}$ and $\mathrm{b}$ are calibrated to an initial levels of sales at prevailing prices, given an assumed price elasticity at a fixed market share (e.g., -2.0 at 50\%). 
Note that hydrogen infrastructure, availability and cost are not explicitly modeled in this analysis due to time limitations. Hydrogen availability and cost is likely to be most critical for BuP applications where some locations will be remote or not easily accessible and the quantity of hydrogen use per year will generally be small. In our assessment, we have assumed, that not all BuP site will be suitable for hydrogen fuel cells and that in the course of learning through experience and with the evolution of a substantial market for hydrogen for BuP and MHE applications, hydrogen suppliers will find acceptable solutions for the rest, and will be able to sell hydrogen at a cost of \$7-\$8 per $\mathrm{kg}$. Clearly, this assumption can be challenged and should itself be assessed.

\subsection{KEY ASSUMPTIONS AND SCENARIO DEFINITIONS}

The validity of any model's outputs is no greater than the validity of its inputs. In deciding on the key parameters of our model we have attempted to choose reasonable but conservative values, and to clearly explain our assumptions. If conservative yet plausible assumptions lead to the conclusion that a government acquisition program would play a decisive role in creating a stable North American PEM fuel cell industry, then there is reason to seriously consider implementing such a program.

The phenomenon of cost reduction in manufacturing via learning-by-doing has been repeatedly documented and measured. Still, no theory or methodology exists for predicting learning rates for new technologies in advance. The standard learning model can be characterized by a progress ratio, the ratio of costs with each doubling of cumulative production. For example, a progress ratio of 0.8 implies a $20 \%$ cost reduction with each doubling of cumulative production. A comprehensive review of the literature found a range of progress ratios from 0.72 at the lower tail of the distribution to 0.96 at the upper tail, with a mean of 0.82 , for 108 studies (IEA, 2000).

The standard learning model allows cost reduction to continue indefinitely. The asymptotic model we use here places a limit on cost reduction. The asymptotic model does not have a single progress ratio, but an equivalent progress ratio can be calculated. The equivalent progress ratio is defined as the progress ratio that, in a standard learning model, would result in the same cost reduction as the asymptotic model at a specified cumulative production. In Table 5 below, equivalent progress ratios are shown for OEMs and stack manufacturers at cumulative production levels of 500,000 and 1,000,000, respectively. For OEMs the units of cumulative production are fuel cell systems, while for stack manufacturers the units are kWs of stacks produced. For OEMs the equivalent progress ratio is 0.91 and for stack manufacturers the ratio is 0.95 . Figures 2 and 3 show the difference between the asymptotic model and the more traditional power function learning model over the range of interest. For both models cost reduction will continue beyond the end points of the curve shown in the figures, but at different rates. As is evident in the graphs, progress is initially slower with the asymptotic model. Also shown in Table 5 are the asymptotic values, which imply that stack manufacturers can eventually reduce stack costs by $34 \%$, while OEMs can eventually reduce the remainder of system costs by $50 \%$. 
Table 5. Learning Curve Assumptions and Parameters

\begin{tabular}{lcc}
\hline & OEMs & Stack Manufacturers \\
\hline Asymptote & 0.50 & 0.66 \\
A & 0.525 & 0.350 \\
B & -20 & -20 \\
Scaling Cumulative Production & 500,000 & $1,000,000$ \\
Comparable Progress Ratio & 0.91 & 0.95 \\
\hline
\end{tabular}

\section{Learning-by-doing Curves: Stacks}

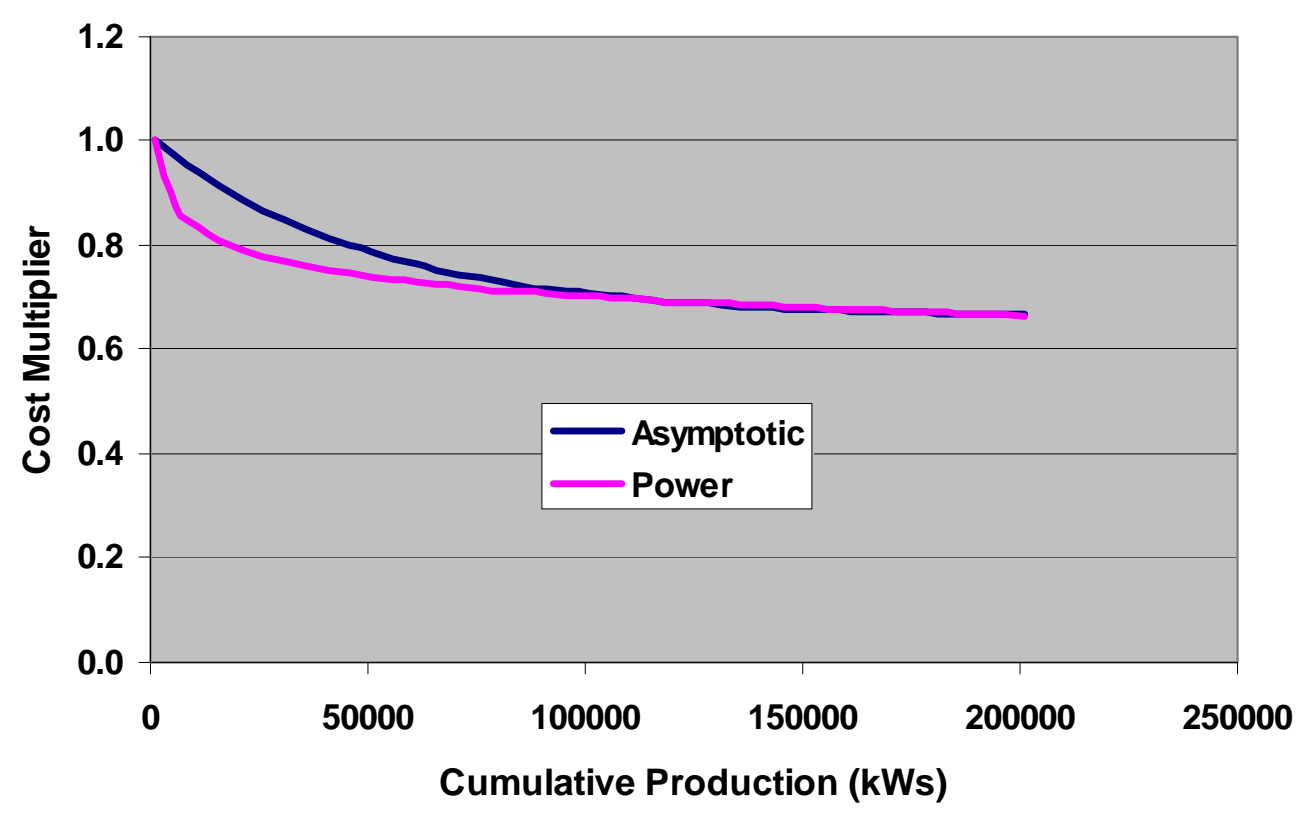

Figure 2. Asymptotic and power function experience curves for stack manufacturers.

Scale economies are distinct from learning-by-doing and reflect primarily the ability to distribute fixed costs over more units as production increases. The key parameter is the scale elasticity, which measures the percent change in unit cost for a $1 \%$ increase in production volume. We assume a scale elasticity of -0.2 (based on the authors' judgment) for both OEMs and stack manufacturers, implying that a $1 \%$ increase in production volume would decrease costs by $0.2 \%$. Cost reductions are limited by assuming that once the production volume has reached "full scale," no further cost reductions are possible (i.e., another plant must be built). We assume full scale for OEMs is 9,000 units per year while full scale for stack manufacturers occurs at 20,000 units per year. Another key assumption is the unit cost today at a given production volume. In choosing these points we have relied on our own survey of PEM fuel cell system purchasers as well as confidential information provided to us by manufacturers. We assume that a fully installed fuel cell $5 \mathrm{~kW}$ fuel cell system would cost $\$ 30,000$ today at a production volume of 1,000 units per year, and that a $1 \mathrm{~kW}$ stack would cost $\$ 2,000$ at a scale of 5,000 units per year. 


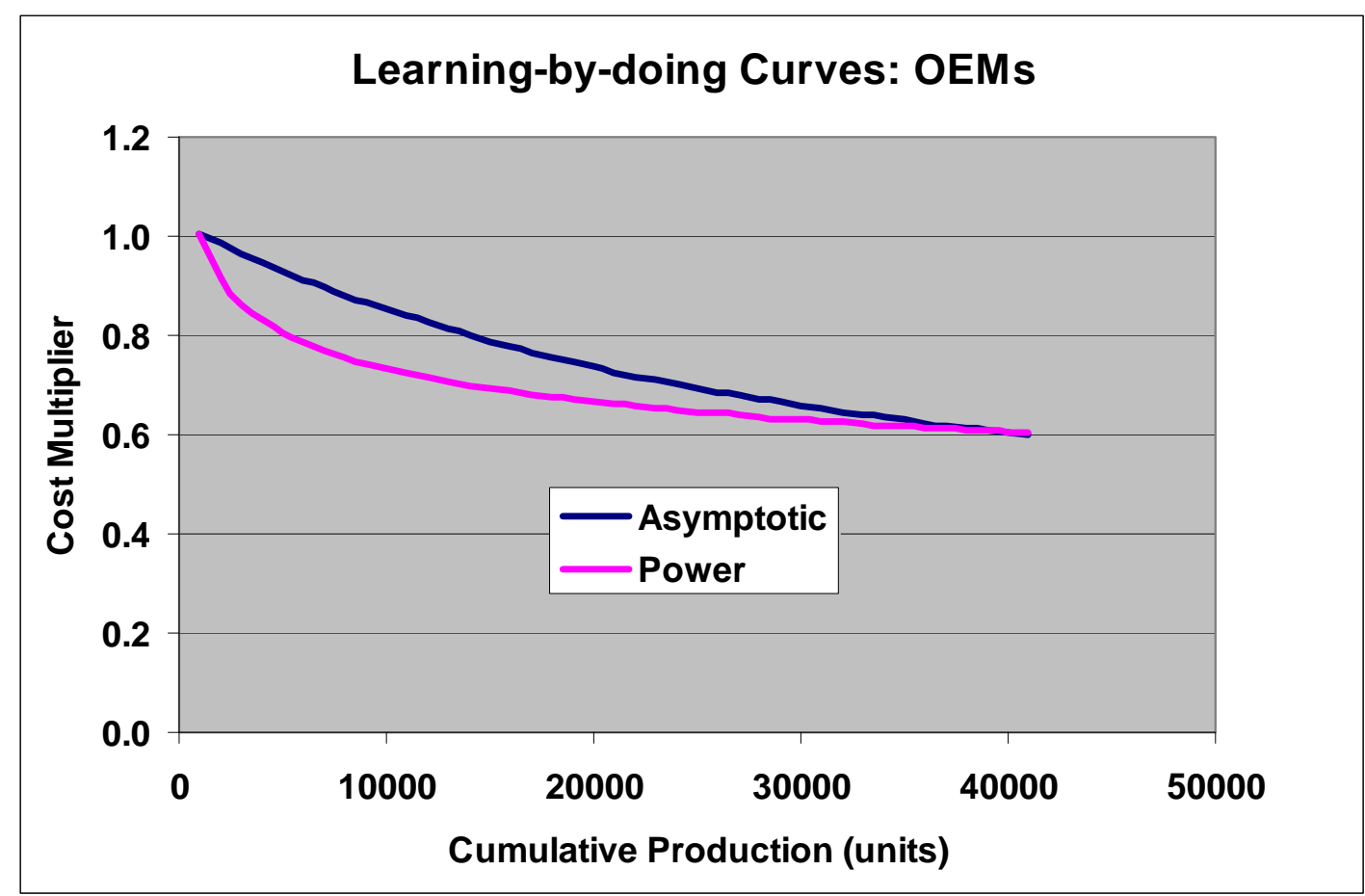

Figure 3. Asymptotic and power function experience curves for OEMs.

Because scale economies and learning are modeled separately for stacks and OEMs, an initial cost breakdown among components must also be assumed. We make use of the assumptions in Table 6 and further assume that the cost shares of stack, balance of plant (BoP) and hydrogen storage and supply equipment are $1 / 3,1 / 3,1 / 3$ for a $5 \mathrm{~kW}$ backup power unit (based on discussions with industry sources). We also assume that the stack cost for MHE is half the cost per $\mathrm{kW}$ of $\mathrm{BuP}(\$ 1,000$ versus $\$ 2,000)$. Taken together, these assumptions imply the cost breakdowns shown in Table 7 for the three types of PEM fuel cell systems.

Table 6. Scale Economy Assumptions

\begin{tabular}{lcc}
\hline & $\begin{array}{c}\text { OEMs } \\
(5 \mathrm{~kW} \text { system })\end{array}$ & $\begin{array}{c}\text { Stack Manufacturers } \\
(1 \mathrm{~kW} \text { stack })\end{array}$ \\
\hline Scale elasticity & -0.20 & -0.20 \\
Full scale economies at (units/year) & 9,000 & 20,000 \\
Current breakeven cost (\$/unit) & $\$ 30,000$ & $\$ 2,000$ \\
Units/year to reach breakeven cost & 1,000 & 5,000 \\
Number of manufacturers & 5 & 3 \\
\hline
\end{tabular}


Table 7. Initial Year Cost Assumptions for Fully Installed Fuel Cell Systems (Assumes stack cost to OEM of $\$ 2,000 / \mathrm{kW}$ for BuP, $\$ \mathbf{1 , 0 0 0 / k W}$ for MHE)

\begin{tabular}{lcccc}
\hline & System Cost & Stack & BoP & H2 Supply \\
\hline $5 \mathrm{~kW} \mathrm{BuP}$ & $\$ 30,000$ & $\$ 10,000$ & $\$ 10,000$ & $\$ 10,000$ \\
& & $(33 \%)$ & $(33 \%)$ & $(33 \%)$ \\
$1 \mathrm{~kW} \mathrm{BuP}$ & $\$ 12,000$ & $\$ 2,000$ & $\$ 5,000$ & $\$ 5,000$ \\
& & $(17 \%)$ & $(42 \%)$ & $(42 \%)$ \\
$5 \mathrm{~kW} \mathrm{MHE}$ & $\$ 25,000$ & $\$ 5,000$ & $\$ 10,000$ & $\$ 10,000$ \\
& & $(20 \%)$ & $(40 \%)$ & $(40 \%)$ \\
\hline
\end{tabular}

The response of the marketplace to reductions in fuel cell system costs is determined by multiplying total annual sales by the PEM fuel cell system share. The fuel cell system share is a logit function of the fuel cell system price. The key parameters are the price elasticities, and the target prices at which $50 \%$ of the markets could be captured by PEM fuel cell systems. We assume a price elasticity of -1.5 at a $50 \%$ market share. This implies that a $1 \%$ price reduction would produce a $1.5 \%$ increase in demand at the $50 / 50$ point. From these assumptions the price coefficients and constant terms of the logit model can be calculated (Table 8). This method of calibration assumes that the price and attributes of the alternative (battery systems) remain constant over the analysis period. The resulting functions predicting market share as a function of installed system cost are shown in Figure 4.

Table 8. Logit Choice Model Assumptions and Parameters

\begin{tabular}{llll}
\hline & $1 \mathrm{~kW} \mathrm{BuP}$ & $5 \mathrm{~kW} \mathrm{BuP}$ & $5 \mathrm{~kW} \mathrm{MHE}$ \\
\hline Price elasticity & -1.5 & -1.5 & -1.5 \\
Target price & $\$ 15,000$ & $\$ 5,000$ & $\$ 12,500$ \\
Market share at target price & $50 \%$ & $50 \%$ & $50 \%$ \\
Price slope & -0.00020 & -0.00060 & -0.00024 \\
Constant & -3.0 & -3.0 & -3.0 \\
\hline
\end{tabular}

Four scenarios were analyzed with the model. The Base Case scenario (0) assumes no federal government acquisitions program, but that states and local governments will continue to purchase a total of 200 units per year, distributed as $1001 \mathrm{~kW} \mathrm{BuP} \mathrm{units,} 505 \mathrm{~kW}$ BuP units and $505 \mathrm{~kW}$ MHE units. The private market will respond to lower prices according to the choice equations described above. Scenario 1 assumes that a federal acquisition program begins in the current year (2008) at a low level by matching the state and local purchases of 200 units per year. This increases each year, reaching a total of 2,175 units in 2012 (Figure 5). The vast majority of the units are $1 \mathrm{~kW}$ BuP units, assumed to be used in FAA towers, as shown above in Table 3. Scenario 2 is the same as Scenario 1, except that the market is assumed to be twice as sensitive to price as in Scenario 1. This will have the effect of making fuel cells initial penetration of the private market more difficult but will lead to a faster transition once cost targets are reached. Scenario 3 assumes the increased price sensitivity of Scenario 2, but assumes a much less aggressive federal acquisitions program. Federal purchases do not begin until 2011, and then are only half the levels shown in Figure 5. 


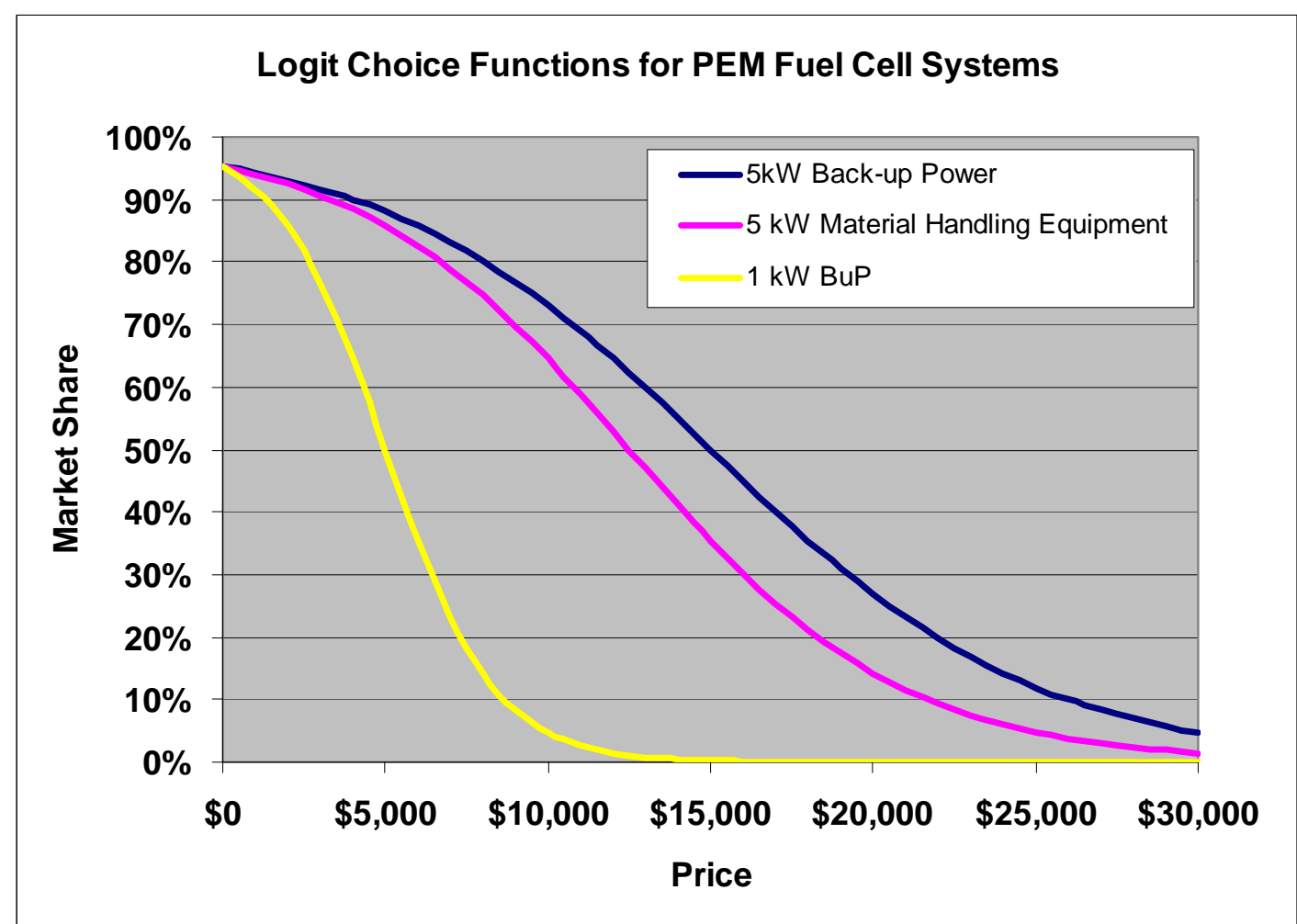

Figure 4. Choice functions determining fuel cell market shares as a function of price.

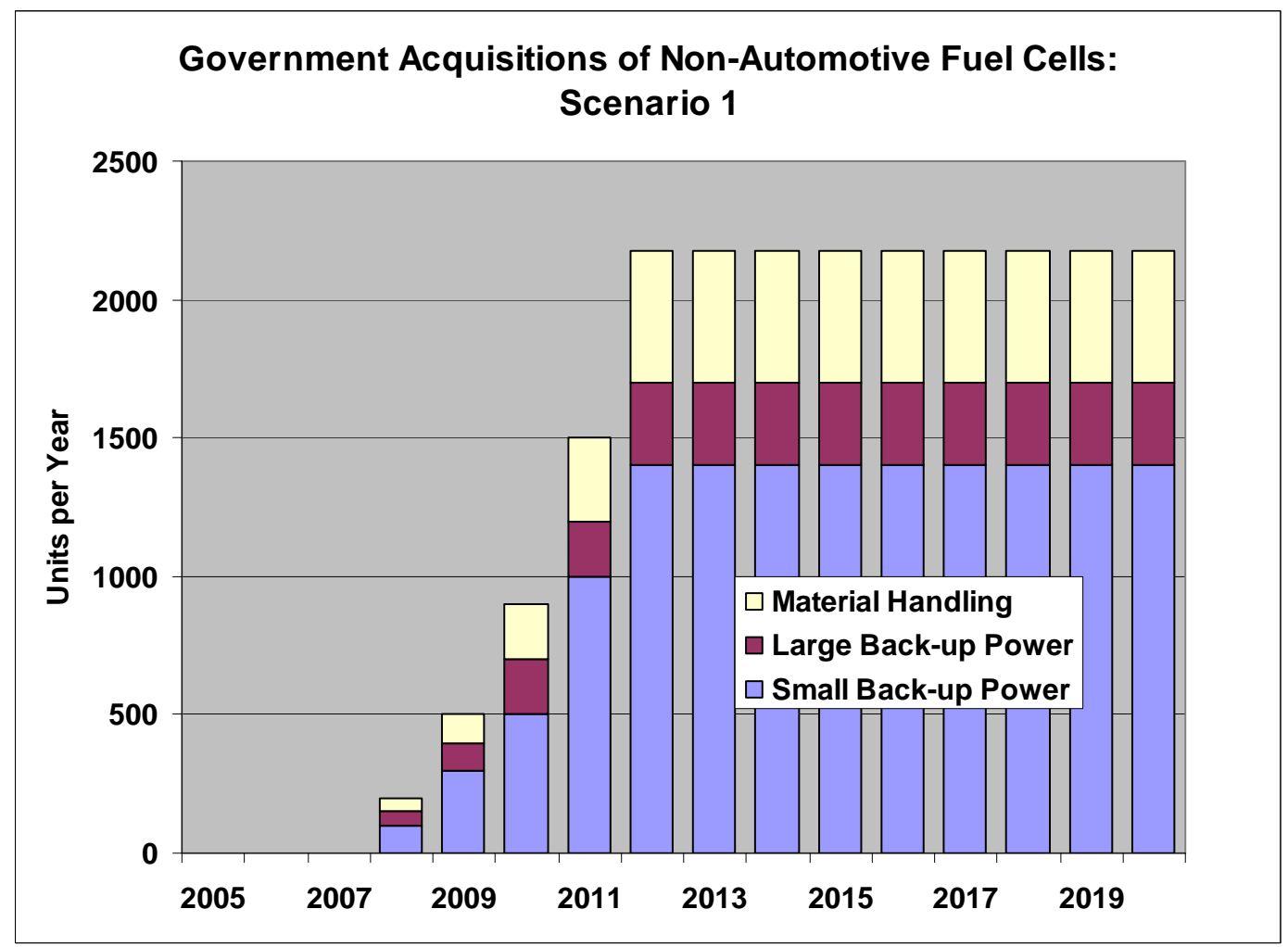

Figure 5. Assumed federal acquisitions of non-automotive fuel cells in Scenario 1. 


\subsection{RESULTS}

Based on the projections of our model, an aggressive government acquisitions program would have a significant beneficial impact on the costs of non-automotive PEM fuel cells, and might create a stable private sector market by 2015 . In the absence of a federal acquisitions program the assumed purchases by states and local governments plus estimated private market purchases are not sufficient to drive PEM fuel cell system costs down to competitive levels (Figure 6). System costs remain at about the same levels through 2015 and beyond. The aggressive program of Scenario 1, on the other hand, reduces costs for all systems to near their competitive target levels by 2015 and reaching those levels by 2020. Stack costs are reduced by a factor of three over current levels (Figure 7).

In the absence of a federal acquisition program market demand is negligible and total units produced each year is barely above the assumed 200 state and local government purchases per year (Figure 8, left hand axis). The data points for 2005-2007 are based on historical estimates and are not model predictions. By one estimate, the annual production volume for one OEM must exceed 1,000 units per year to achieve profitability (Perry and Strayer, 2006). The dramatic cost reductions brought about by the federal program stimulate private sector demand, creating a market of 35,000 units per year by 2020 (Figure 8, right hand axis).

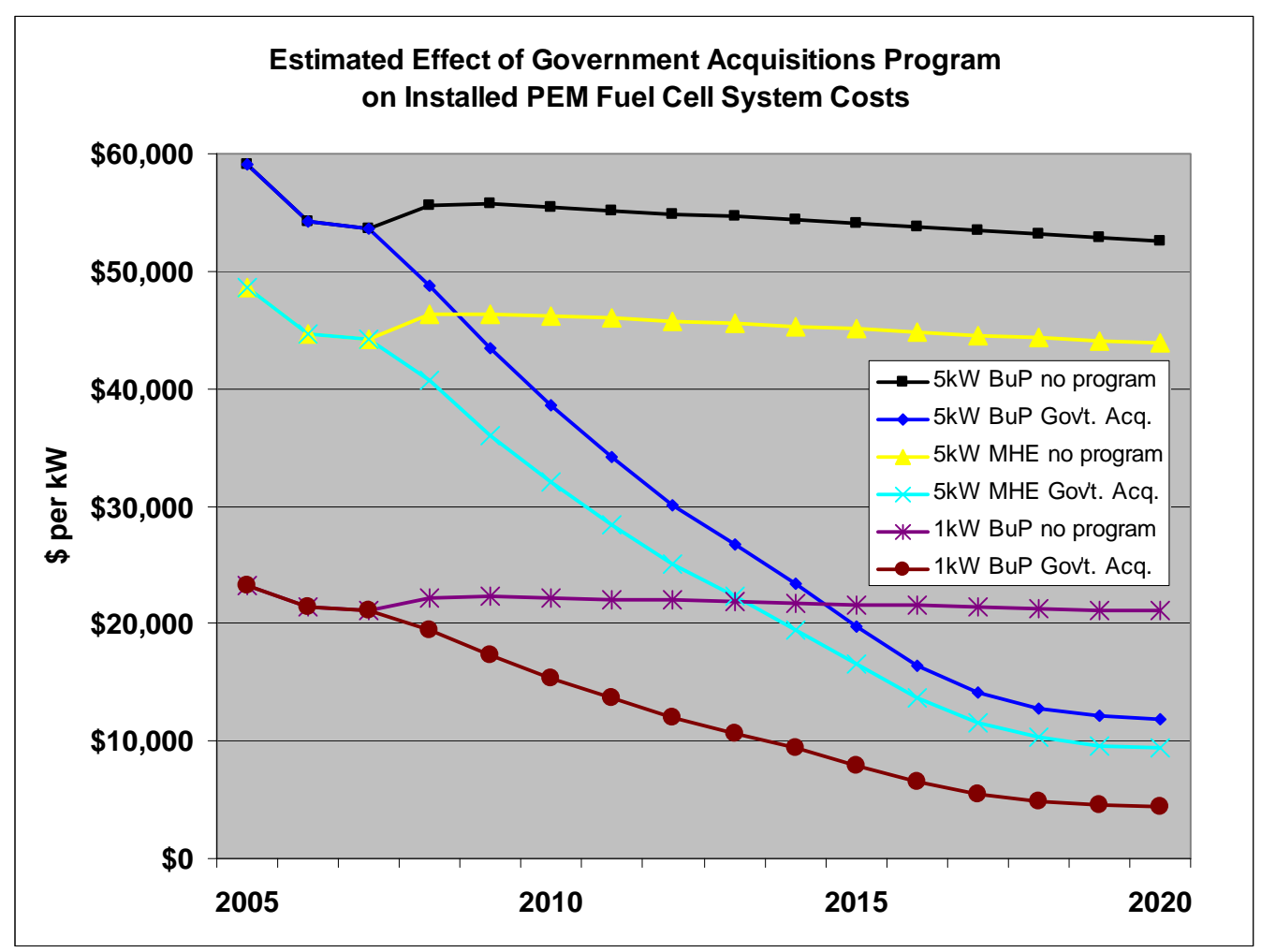

Figure 6. Estimated effect of federal acquisitions program on PEM fuel cell system costs: Scenario 1. 


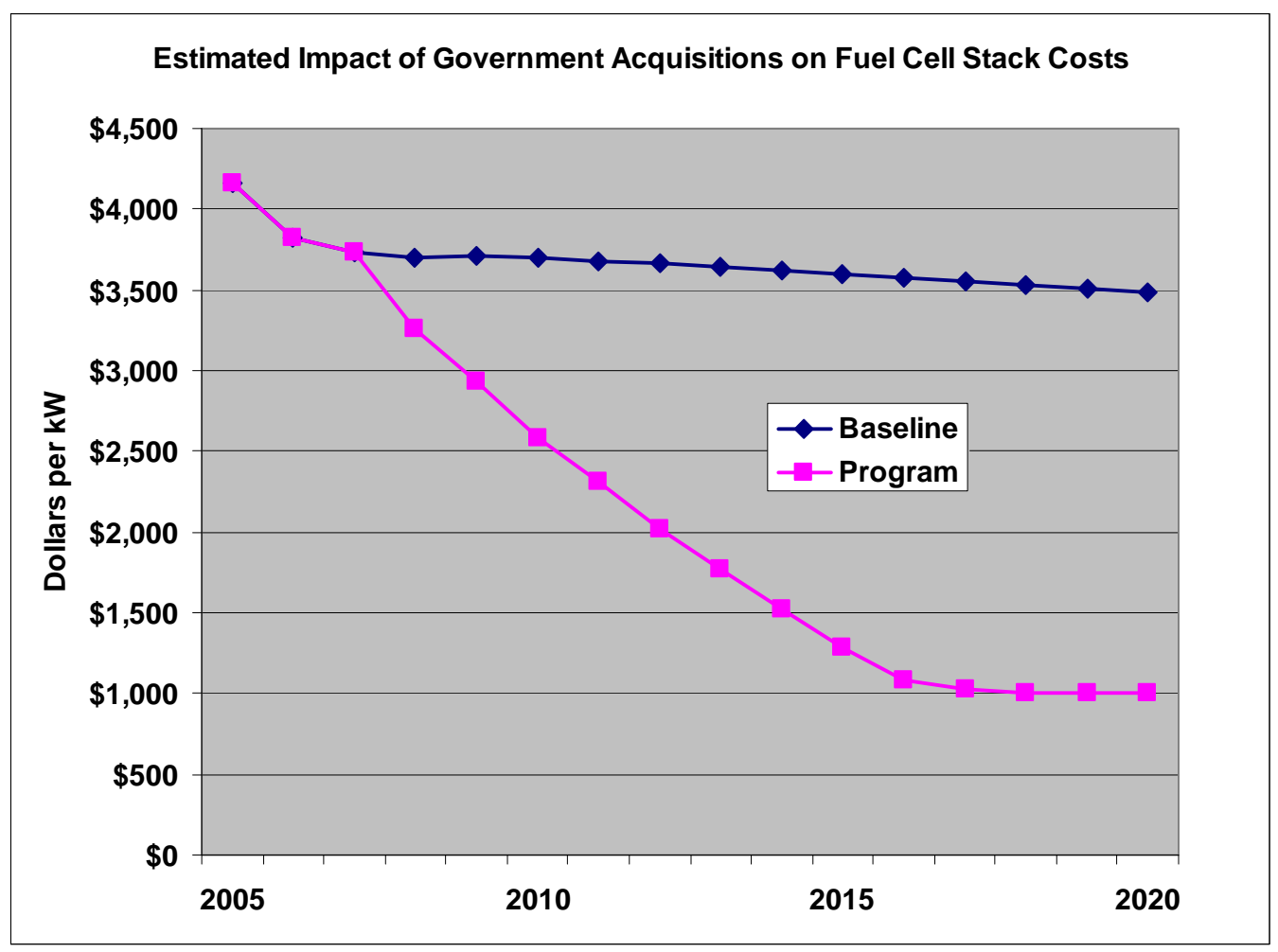

Figure 7. Estimated impact of federal acquisitions program on PEM fuel cell stack costs: Scenario 1.

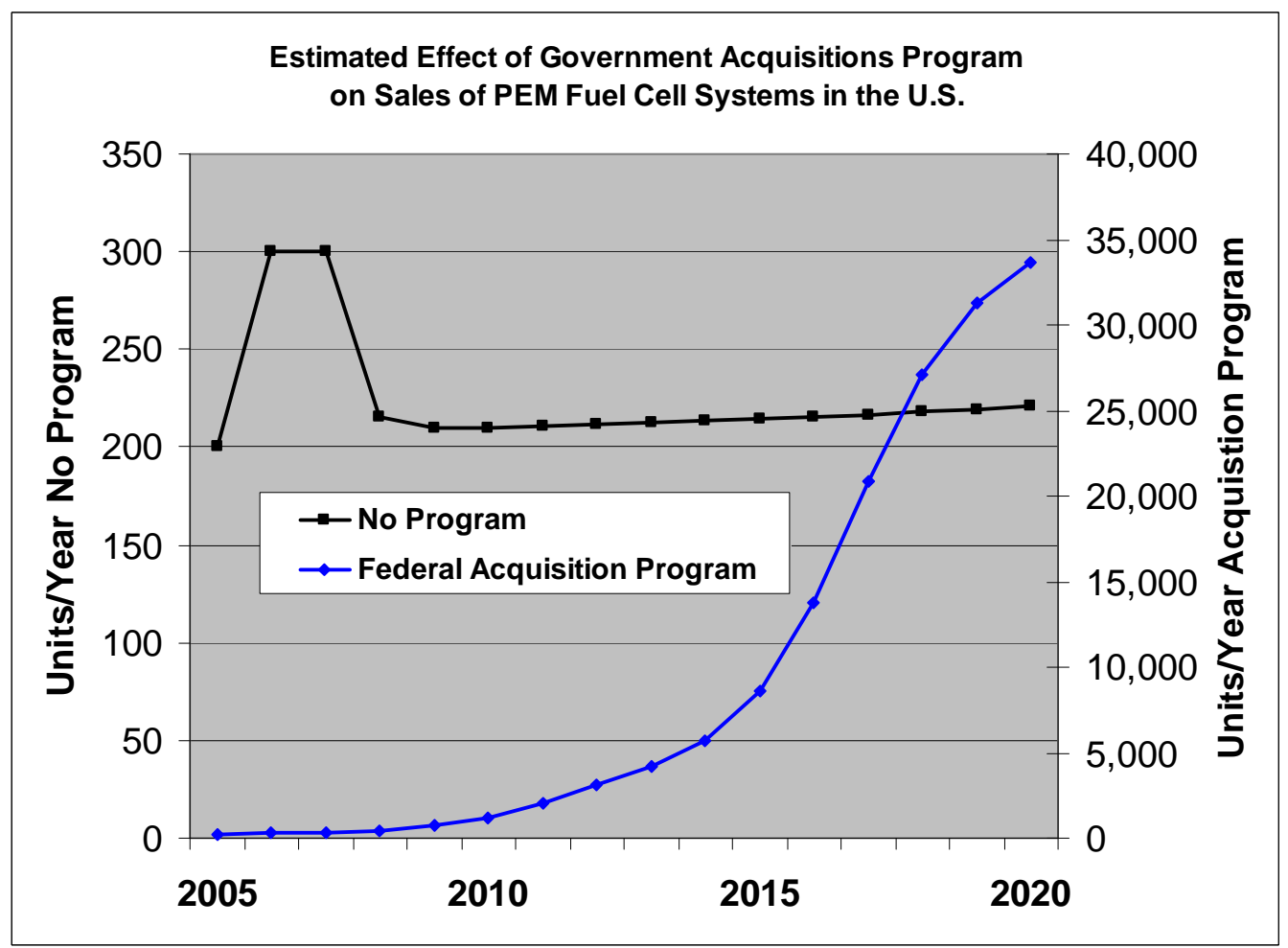

Figure 8. Estimated effect of federal acquisitions on PEM fuel cell system sales: Scenario 1. 
Without the acquisition program the gross revenues of OEMs are nearly flat at under $\$ 3$ million per year (Figure 9). This is clearly insufficient to sustain even one firm, let alone a nonautomotive fuel cell industry. It is just a question of when the firms will exit. With the aggressive acquisition program gross revenues grow exponentially to over $\$ 50$ million per year in 2014 , continue rising rapidly to over $\$ 100$ million in 2016 , and then begin to level off at just over \$200 million. This results in a modest industry that should be able to sustain 4-5 small OEMs. This study has not considered whether the lower costs of fuel cell systems would open up new markets beyond the three included in our model.

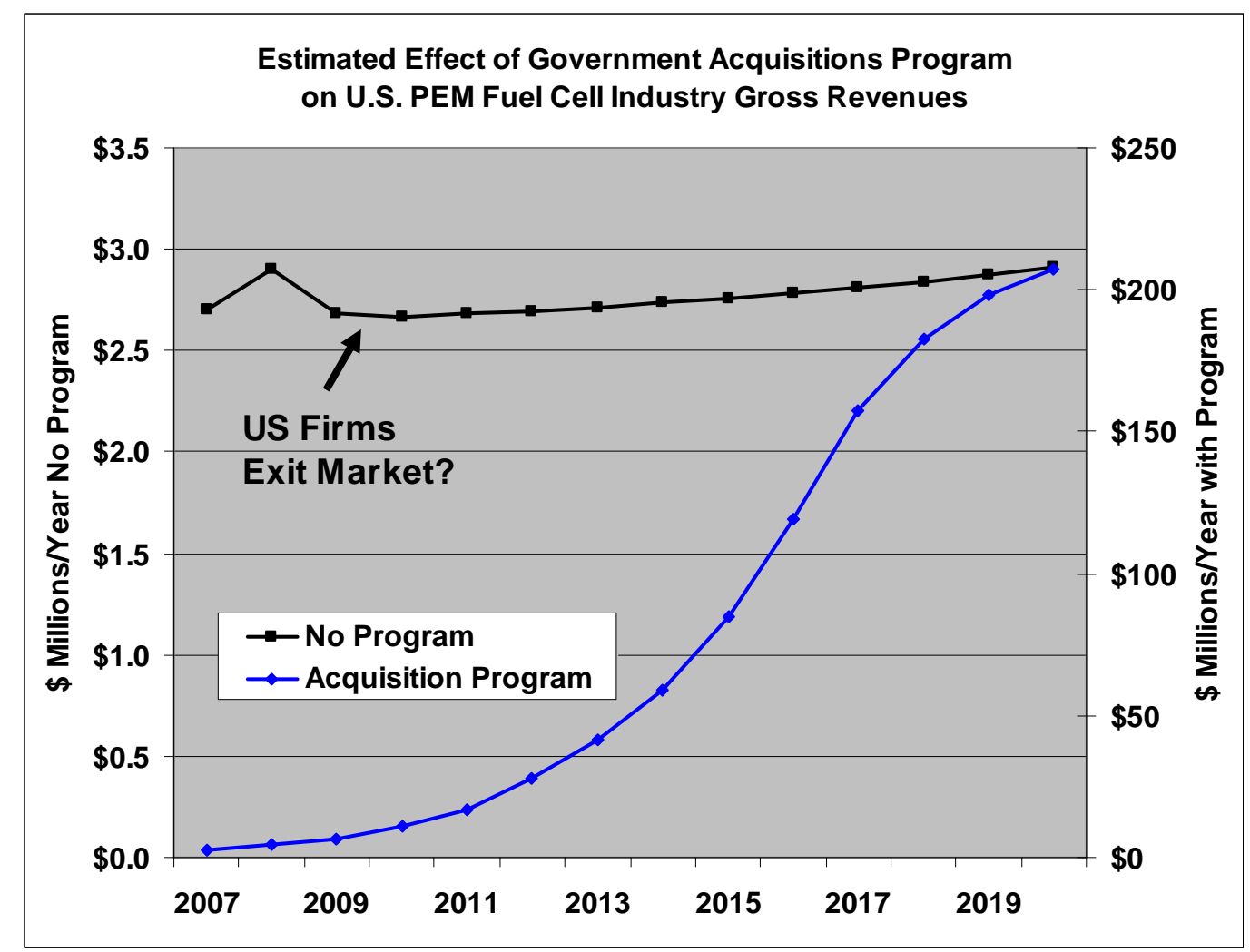

Figure 9. Estimated effect of federal acquisitions program on PEM fuel cell manufacturers' gross revenues: Scenario 1.

Gross federal expenditures for the Scenario 1 acquisition program rise from about $\$ 6$ million in 2008 peaking at $\$ 37-\$ 38$ million in 2012 (Figure 10). After 2012, gross expenditures fall as the number of units purchased remains constant and costs per unit fall. Net costs, the total costs of fuel cell acquisitions minus the cost of the battery units they replace would be significantly smaller. Our estimates, however, do not include any additional training or other start-up costs for the fuel cell program. 


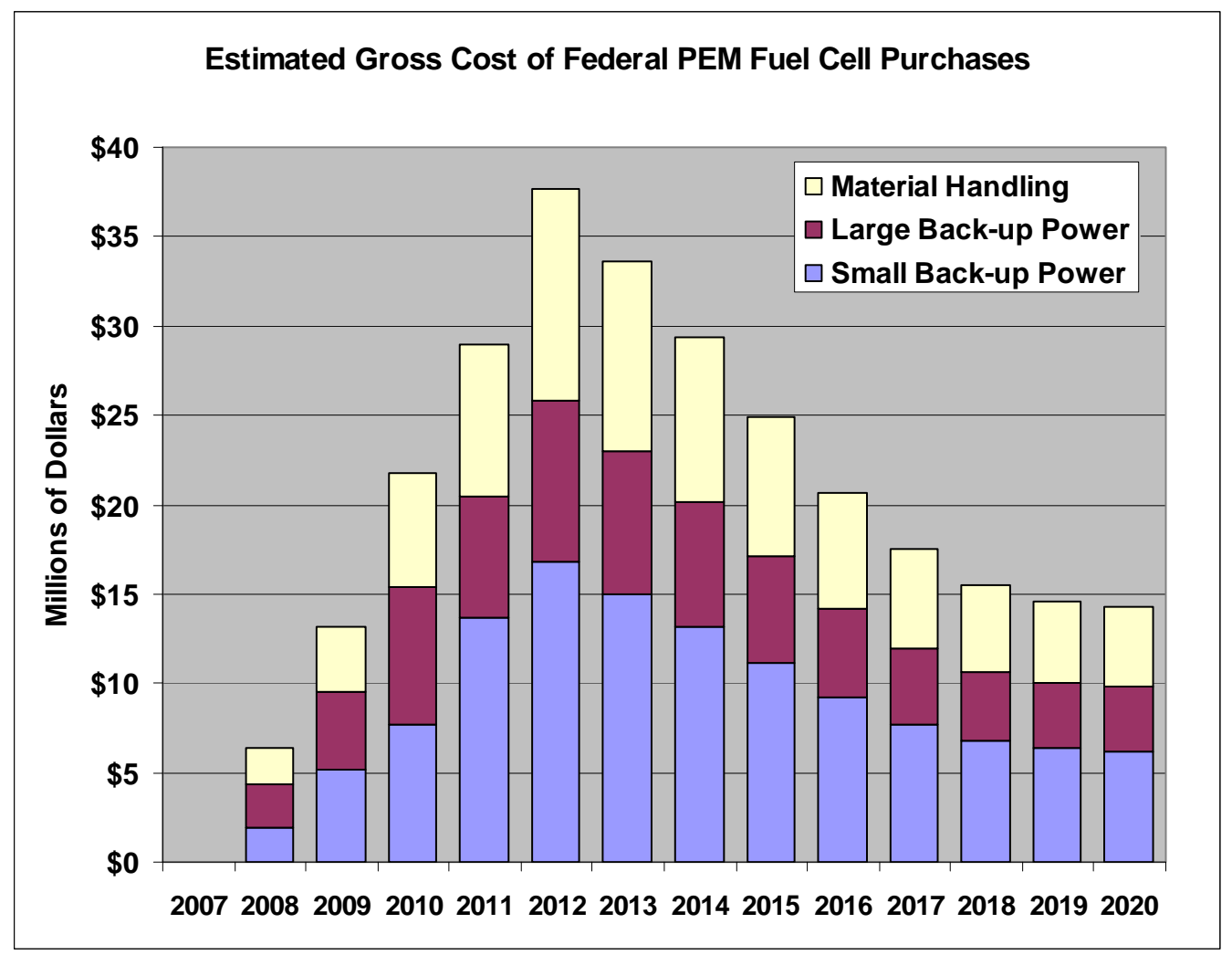

Figure 10. Estimated gross cost of federal PEM fuel cell system purchases: Scenario 1.

The sensitivity of choice of power system (fuel cell or battery) to price is the key parameter in the logit choice model that predicts the market's response to lower fuel cell system costs. Doubling the price sensitivity makes it more difficult for fuel cell systems to make inroads while they are more expensive than battery powered systems. On the other hand, once fuel cells approach their price targets their market penetration will be more rapid. As can be seen in Figure 11 , the estimated impact of doubling the price sensitivity of the choice model is to significantly delay the market response to the federal acquisitions program. By 2015 the private sector markets are only just barely beginning to respond. Compare this to Scenario 1 in which uses the reference assumption about price sensitivity. In Scenario 1 private markets have begun to switch to fuel cells even before the federal program peaks in 2012. Once the federal program reaches its maximum level in 2012, further increases must come from private sector purchases. Given a higher price sensitivity, the private sector uptake of fuel cell systems is much slower, producing the kink in the fuel cell sales curve in Figure 11. In Scenario 2 with doubled price sensitivity the private markets appear to be poised for take off just before 2020. It is doubtful that the OEMs could stay in business until then, however.

These results suggest that a better understanding of the actual price sensitivity of the market place is needed to reduce uncertainty about the success of a federal acquisitions program. This could be approached by enhancing the model in two ways: (1) empirically estimating the price elasticities of demand for battery BuP and MHE units, and (2) employing a more detailed representation of the cost comparison in the choice model. A more detailed representation would 
explicitly include the prices of both systems, the cost of fuel, and maintenance costs, and would discount future costs to present value.

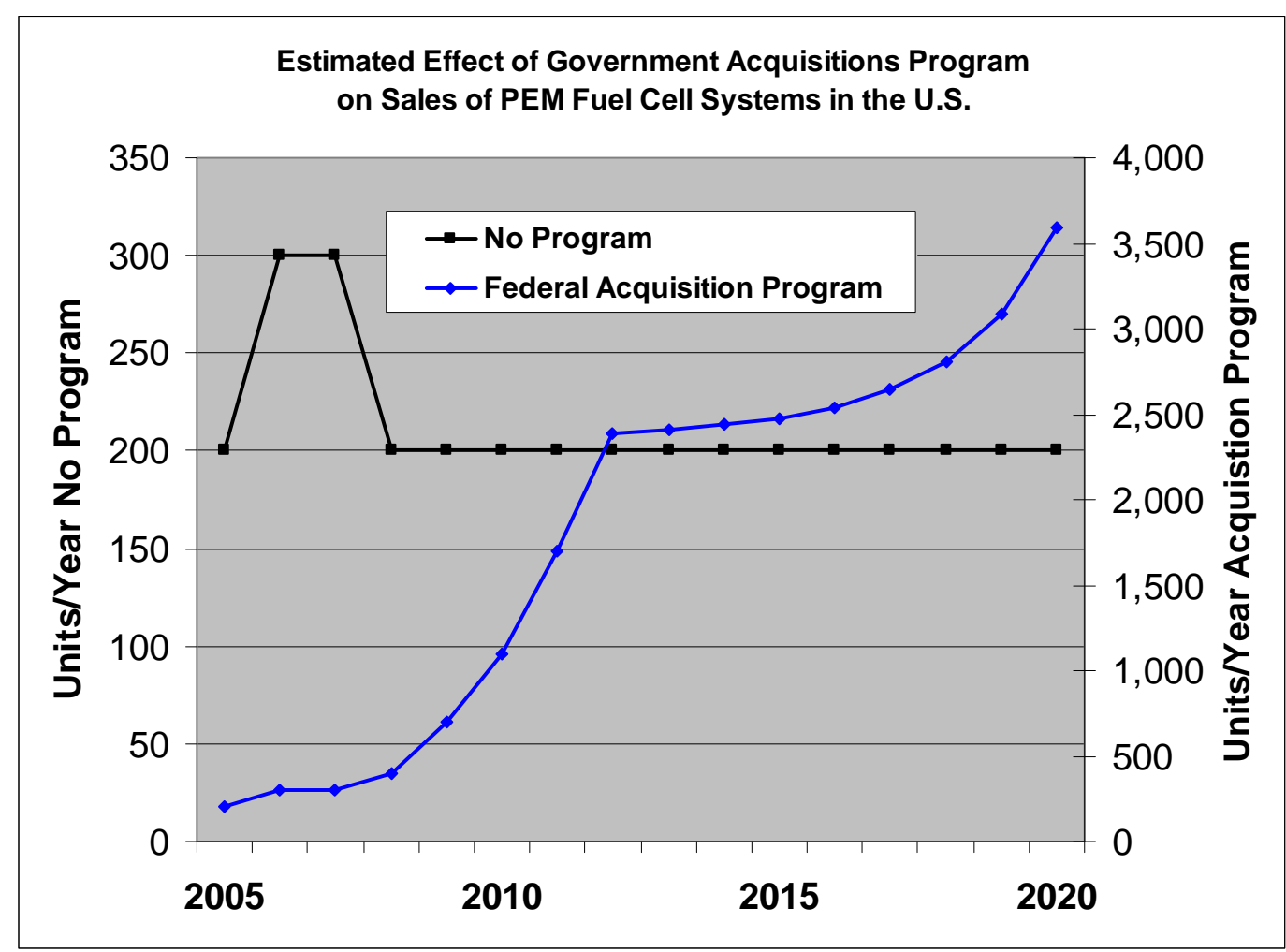

Figure 11. Estimated effect of federal acquisitions program on sales of PEM fuel cell systems: Scenario 2, doubled private sector price sensitivity.

Scenario 3 employs the reference price sensitivity but delays the federal acquisition program to begin in 2011 and cuts federal purchases in half from the reference levels (Figure 12). The smaller, delayed program delays the creation of a private sector market by 3-4 years. Even in 2016 fuel cell system demand is less than 5,000 units per year (Figure 13). By 2020, the private market is growing rapidly in Scenario 3 and gross revenues for OEMs exceed \$150 million Figure 14. However, it is doubtful that OEMs could remain in the market long enough at such low production volumes. As noted above in section 1, the industry's view is that they could not. In Scenario 3 system costs are still roughly twice competitive target levels even in 2015 (Figure 14). The same is true for fuel cell stacks (Figure 15). The slower rate of learning and lower production volumes mean that it takes years longer to reach price levels that allow fuel cells to compete effectively against alternatives. 


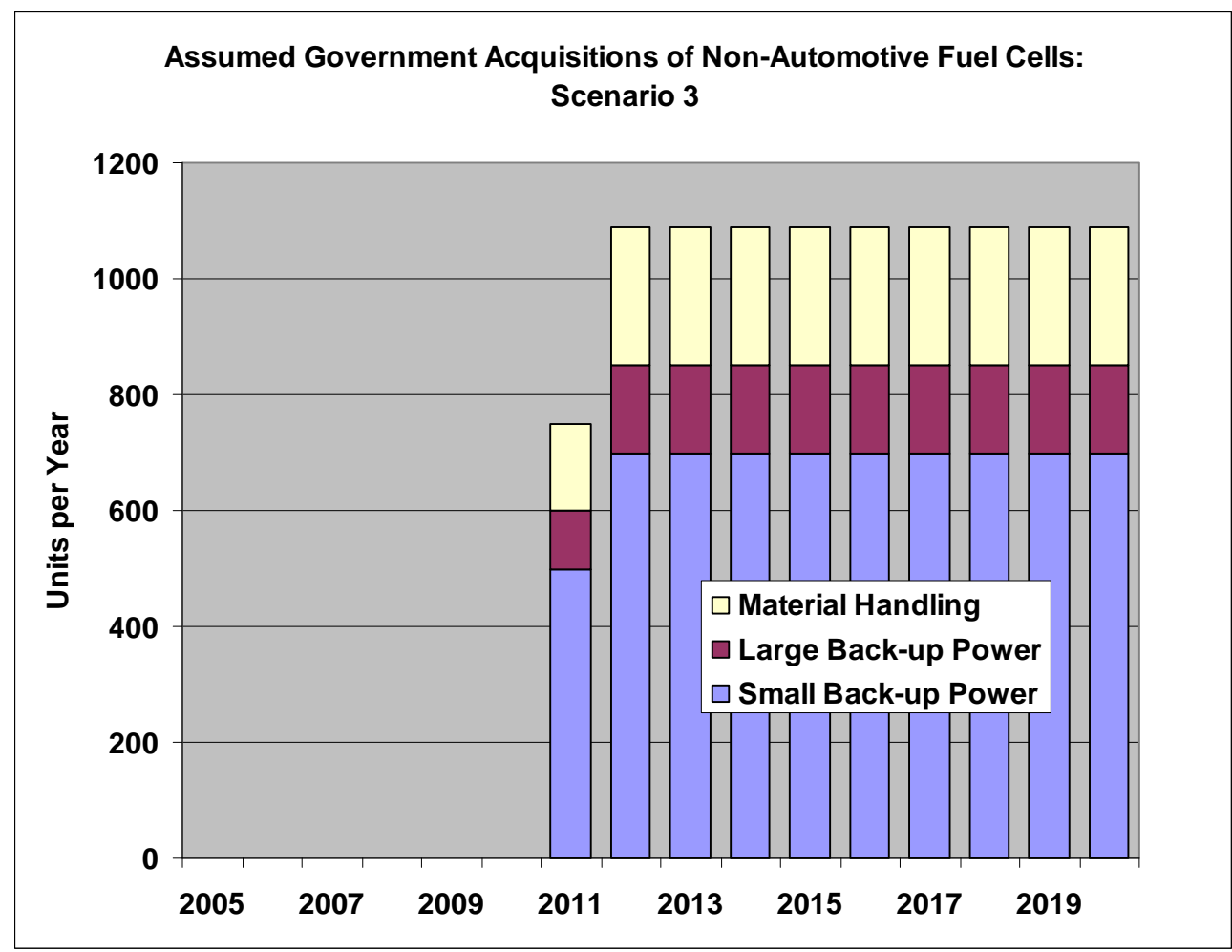

Figure 12. Assumed federal acquisitions of PEM fuel cell systems: Scenario 3.

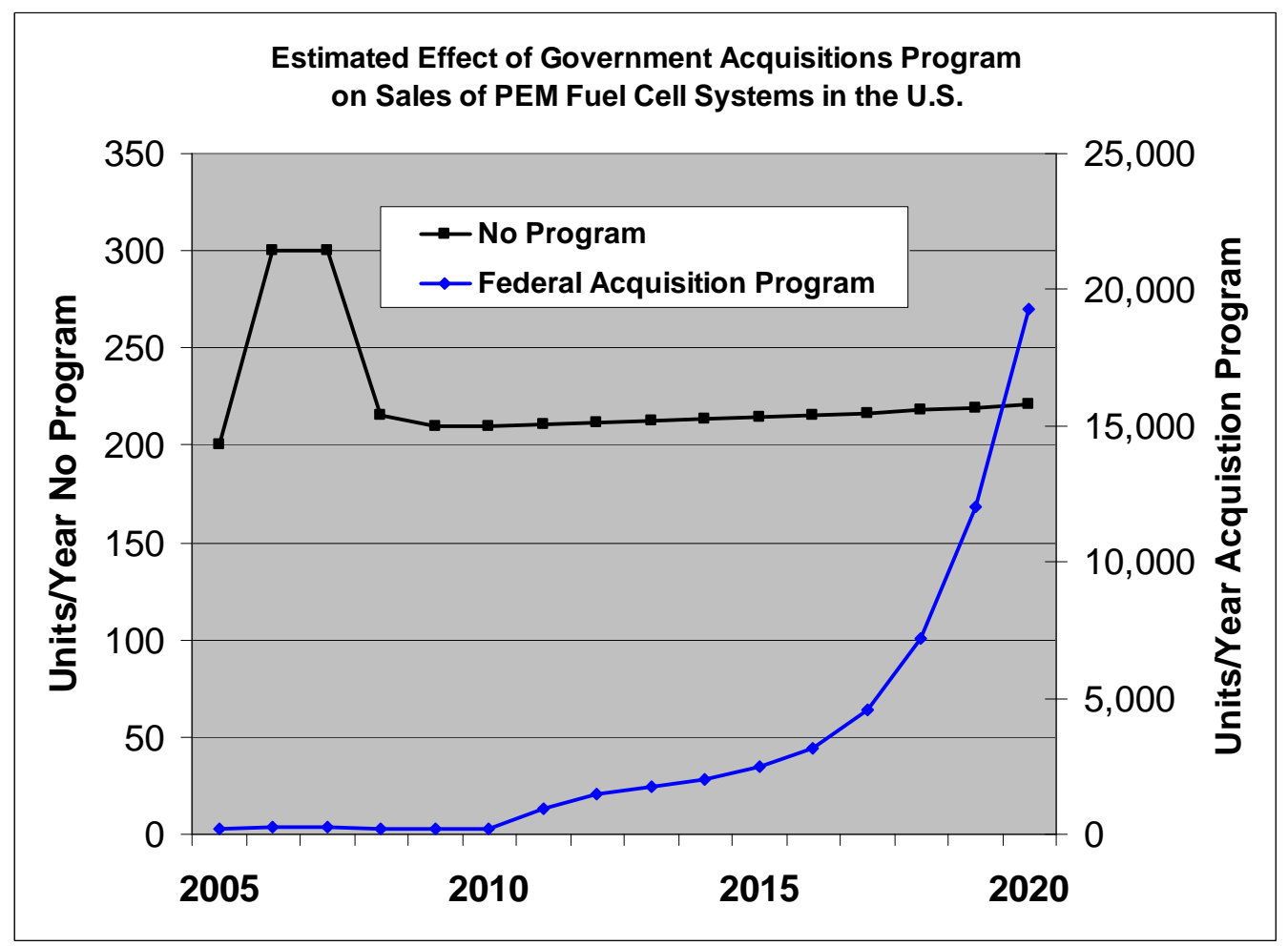

Figure 13. Estimated effect of federal acquisitions on sales of PEM fuel cells: Scenario 3. 


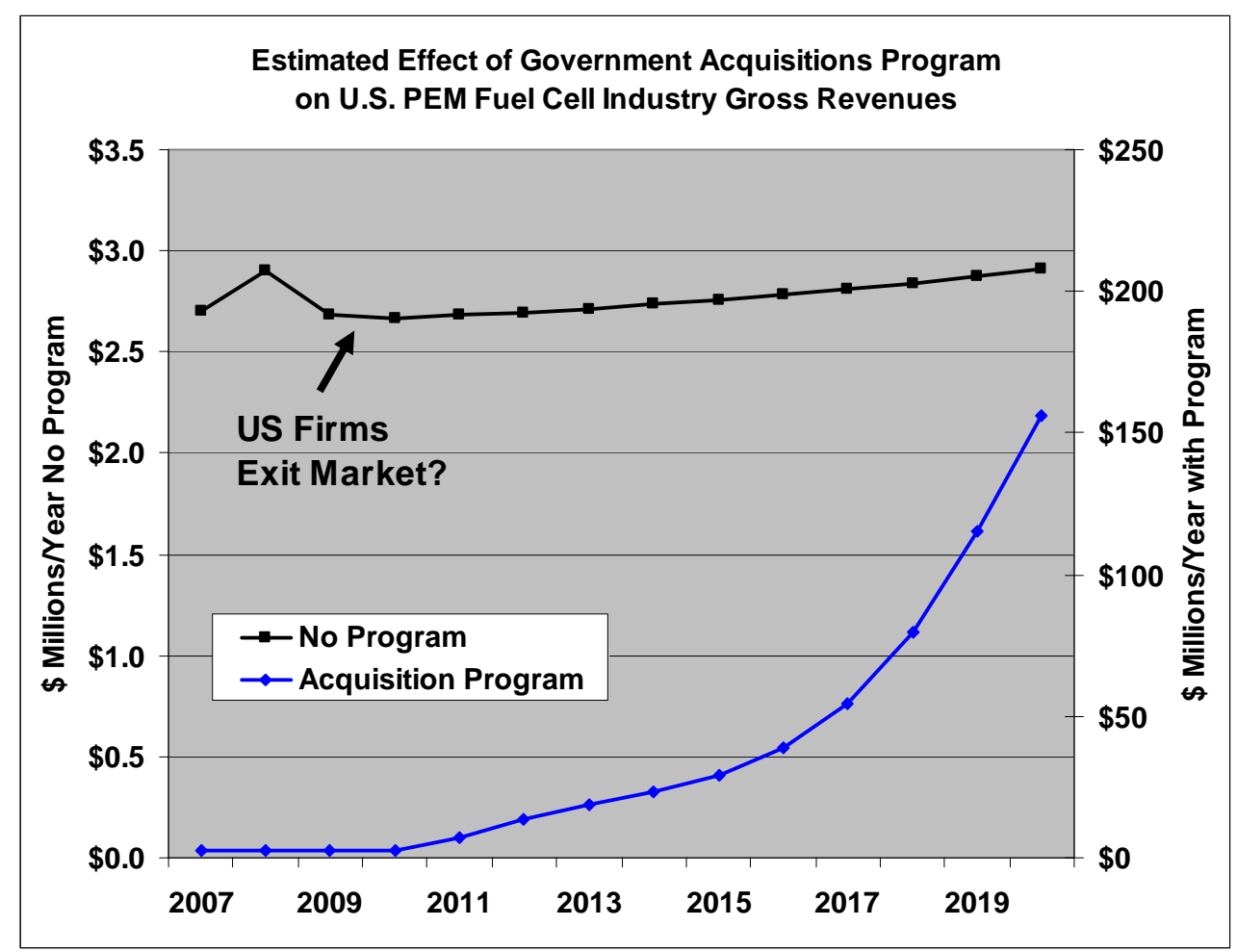

Figure 14. Estimated effect of federal acquisitions on fuel cell system manufacturers' gross revenues: Scenario 3.

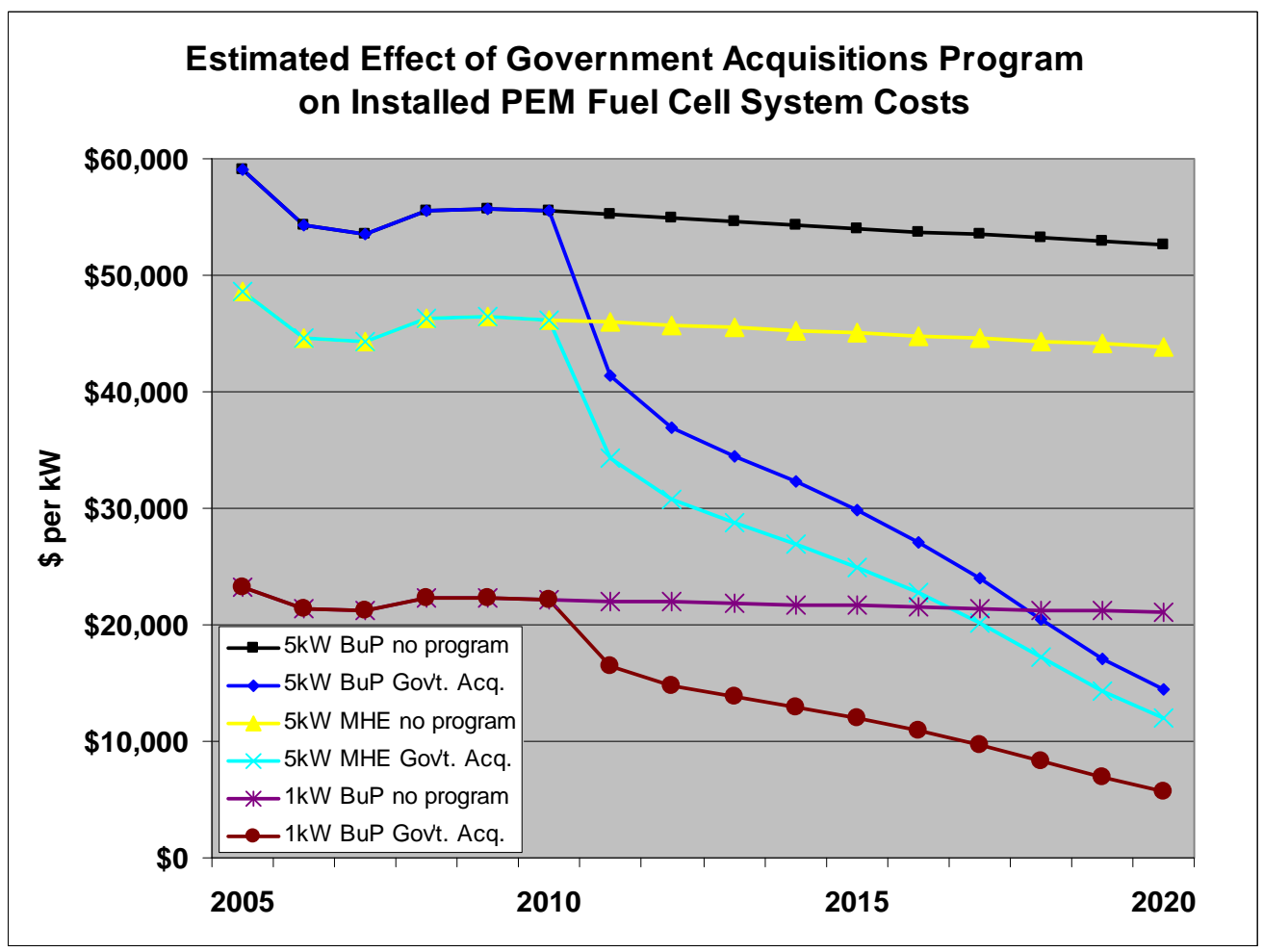

Figure 15. Estimated effect of federal acquisitions on PEM fuel cell system costs: Scenario 3. 


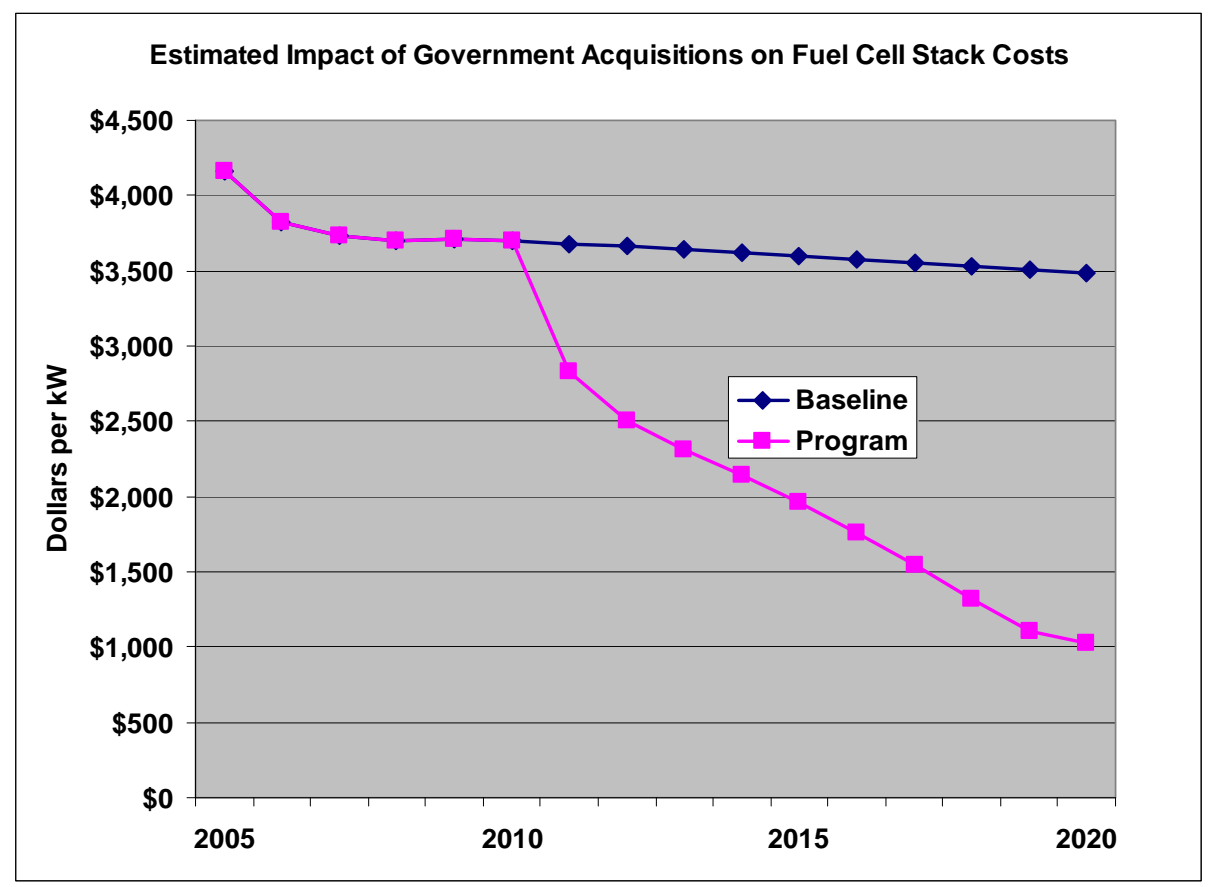

Figure 16. Estimated effect of federal acquisitions on PEM fuel cell stack costs: Scenario 3.

Of course, the delayed and scaled-down acquisition program of Scenario 3 requires a smaller expenditure on the part of the federal government. However, costs are not reduced proportionately because fuel cell system costs remain higher longer in Scenario 3. The sum of undiscounted federal gross costs from 2008 to 2020 in Scenario 1 is \$264 million; in Scenario 3 the same sum is $\$ 167$ million, 63\% of Scenario 1 costs (Figure 17).

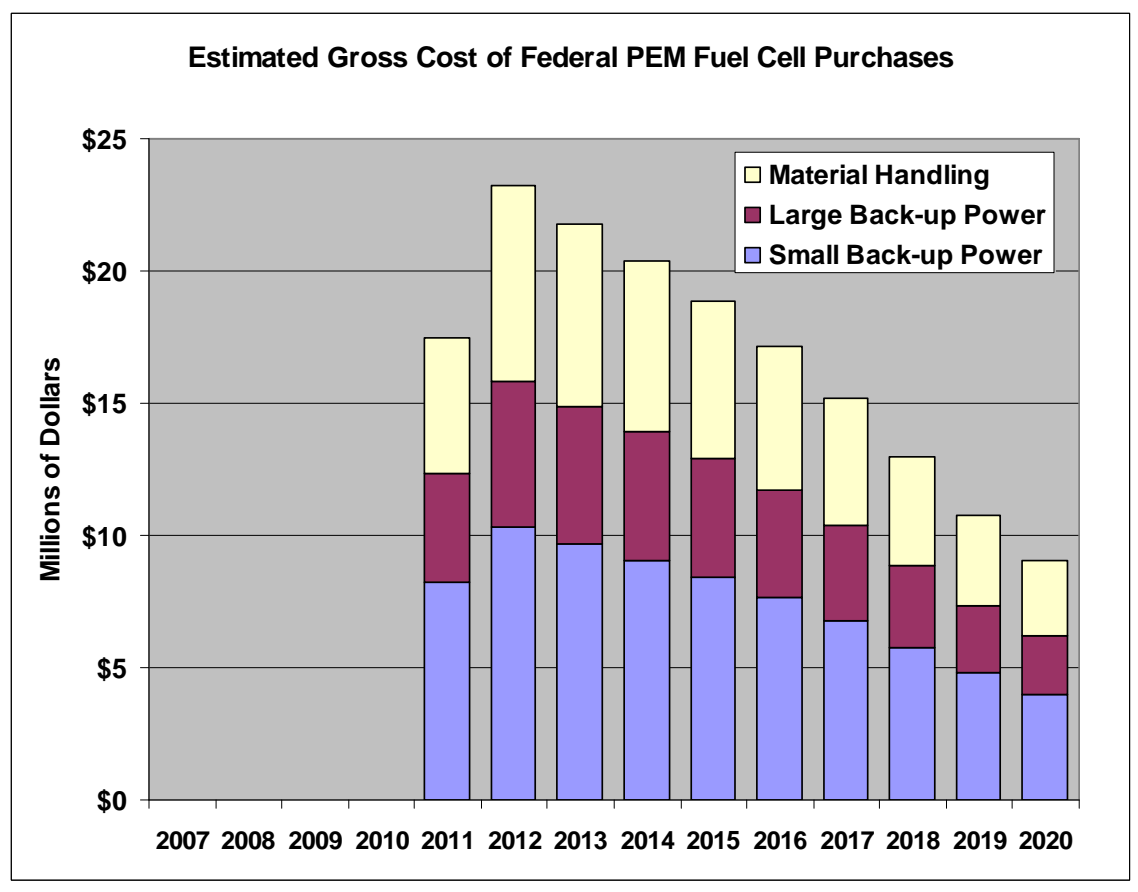

Figure 17. Estimated gross costs of federal acquisitions program: Scenario 3. 


\section{CONCLUSIONS}

Given the many key assumptions made and the inherent difficulty of predicting future technological advances, the conclusions of this study must be considered indicative rather than definitive.

The non-automotive fuel cell industry in North America appears to be at a critical point. If economical production volumes can be reached soon, and if even relatively modest rates of progress via learning-by-doing can be achieved, the industry should be able to produce PEM fuel cell systems for backup power and MHE applications that can compete effectively with current battery powered products. At present, however, production volumes are extremely low and costs are too high, even taking into considerate existing subsidies.

The potential federal market for PEM fuel cell systems in BuP and MHE are large enough to have a significant impact on the industry in terms of both scale economies and learning-bydoing. Plausible assumptions about these two factors imply that an aggressive federal acquisition program, instituted this year at a low level and ramping up to more than 2,000 units per year by 2012 appears to be sufficient to enable the industry to meet its competitive cost targets by 2015. These findings are conditional on plausible but uncertain assumptions about the private sector's response to lower fuel cell prices. Given the size of the potential domestic private sector markets for BuP and MHE, such a federal acquisitions program could establish a small but sustainable North American fuel cell industry based on private sector sales.

There are many areas of uncertainty. This study has not addressed hydrogen supply. Instead it has assumed that as the market expanded, hydrogen supplies would find ways to make hydrogen available at prices in the vicinity of $\$ 7-\$ 8$ per kilogram. This is likely to be more of a challenge for BuP applications than for MHE. Also, this study has not addressed the potential for battery powered alternatives to lower their costs and improve their performance over time.

Finally, many of the parameters used in this analysis are uncertain. Most importantly, little is known about how sensitive the relevant markets are to price. If markets are far more pricesensitive than assumed in this analysis, the evolution of a private sector market could be substantially delayed. If there is an opportunity to carry out additional analysis, improving the representation of private sector demand by explicitly representing utilization rates, energy costs, maintenance costs and dynamically representing the prices of alternative power systems should be given priority. 



\section{REFERENCES}

Greene, D.L., P.N. Leiby, B. James, J. Perez, M. Melendez, A. Milbrandt, S. Unnasch and M. Hooks. 2008. Analysis of the Transition to Hydrogen Fuel Cell Vehicles \& the Potential Hydrogen Energy Infrastructure Requirements, ORNL/TM-2008/30, Oak Ridge National Laboratory, Oak Ridge, Tennessee, March.

(IEA) International Energy Agency. 2000. Experience Curves for Energy Technology Policy, OECD, Paris.

Mahadevan, K., H. Stone, J. Zewatsky, A. Thomas, K. Judd and D. Paul. 2007a. "Market Opportunity Assessment of PEM Fuel Cells in Federal Markets," Battelle, Presentation to the 2007 Fuel Cell Seminar and Exposition, San Antonio, Texas, October 17, 2007.

Mahadevan, K, K. Judd, H. Stone, J. Zewatsky, A. Thomas, H. Mahy, and D. Paul. $2007 \mathrm{~b}$. "Identification and Characterization of Near-Term Direct Hydrogen Proton Exchange Membrane Fuel Cell Markets," prepared by Battelle, Columbus, Ohio for the U.S. Department of Energy under DOE Contract No. DE-FC36-03GO13110, April.

Perry, M. 2007. "Fuel Cells: Not a Threat, More a Partner," Batteries and Energy Storage Technology, Winter 2007, pp. 2-6.

Perry, M.L. and E. Strayer. 2006. "Fuel-Cell Based Backup Power for Telecommunication Applications" Developing a Reliable and Cost-Effective Solution," INTELEC 2006 Proceedings, UTC Power, South Windsor, CT.

Stone, H.J. 2006. "Market Opportunity Assessment for direct Hydrogen PEM Fuel Cells in Transition Markets," Project ID\# FC 32, presentation slides, Battelle Memorial Institute, May 18.

Stone, H.J. 2005. "Economic Analysis of Stationary PEM Fuel Cell Systems," Project ID\# FC 48, presentation slides, Battelle Memorial Institute, May 26.

U.S. Fuel Cell Council. 2006. "2006 Worldwide Fuel Cell Industry Survey,” U.S. Fuel Cell Council, Hydrogen \& Fuel Cells Canada, Fuel Cell Europe, Fuel Cell Commercialization Conference of Japan, PriceWaterhouseCoopers, LLP. 